DOI: $10.5800 /$ GT-2021-12-2-0520

\title{
PRINCIPLES OF TECTONIC MAPPING OF ASIA AND THE ARCTIC, SCALES 1:2500000 - 1:5000000
}

\section{O.V. Petrov ${ }^{1 凶}$, A.I. Khanchuk ${ }^{1,2,3}$, S.P. Shokalsky $^{1}$, G.A. Babin ${ }^{1}$, I.I. Pospelov ${ }^{1,2}$}

\author{
${ }^{1}$ Karpinsky Russian Geological Research Institute, 74 Sredny Ave, Saint Petersburg 199106, Russia \\ ${ }^{2}$ Geological Institute, Russian Academy of Sciences, 7 Pyzhevsky Ln, Moscow 119017, Russia \\ ${ }^{3}$ Far East Geological Institute, Far East Branch of the Russian Academy of Sciences, 159 100-letiya Ave, Vladivostok \\ 690022, Russia
}

ABSTRACT. An overview of the history of tectonic mapping in Russia is presented, and the principles of tectonic mapping are briefly described. Here, out attention is focused on the Tectonic Map of North, Central and East Asia (scale $1: 2500000,2014$ ) and the Tectonic Map of the Arctic (scale 1:5000000, 2019) prepared by international projects of Karpinsky Russian Geological Research Institute (VSEGEI). The projects included participants from geological service agencies, universities and the academies of sciences of 13 countries. We describe the mapping approaches, structural features, legends, graphical design, and information at the map margins. The experience gained with the projects of these two tectonic maps will be used to compile the International Tectonic Map of Asia, scale 1:5000000 (ITMA-5000) and the Tectonic Map of Russia, scale 1:2500000.

KEYWORDS: North, Central and East Asia; the Arctic; tectonic maps; principles of tectonic mapping

FUNDING: The study was carried out under the state task of the Federal Agency for Subsoil Use (project No 04900017-20-04 of December 26, 2019).

\section{REVIEW}

Correspondence: Oleg V. Petrov, OPetrov@vsegei.ru
Received: June 19, 2020

Revised: February 3, 2021 Accepted: February 12, 2021

FOR CITATION: Petrov O.V., Khanchuk A.I., Shokalsky S.P., Babin G.A., Pospelov I.I., 2021. Principles of tectonic mapping of Asia and the Arctic, scales 1:2500000 - 1:5000 000. Geodynamics \& Tectonophysics 12 (2), 173-198. doi:10.5800/GT-2021-12-2-0520 


\title{
ПРИНЦИПЫ СОСТАВЛЕНИЯ ТЕКТОНИЧЕСКИХ КАРТ АЗИИ И АРКТИКИ МАСШТАБОВ 1:2500000-1:5000000
}

\section{О.В. Петров ${ }^{1}$, А.И. Ханчук ${ }^{1,2,3}$, С.П. Шокальский $^{1}$, Г.А. Бабин ${ }^{1}$, И.И. Поспелов ${ }^{1,2}$}

\author{
${ }^{1}$ Всероссийский научно-исследовательский геологический институт им. А.П. Карпинского, 199106, Санкт- \\ Петербург, пр-т Средний, 74, Россия \\ ${ }^{2}$ Геологический институт РАН, 119017, Москва, Пыжевский пер., 7, Россия \\ ${ }^{3}$ Дальневосточный геологический институт ДВО РАН, 690022, Владивосток, пр-т 100-летия Владивостока, \\ 159 , Россия
}

АНнотАЦИЯ. Приведена история развития отечественного тектонического картографирования с краткой характеристикой принципов составления тектонических карт разных лет. Главное внимание уделено Тектонической карте Северной, Центральной и Восточной Азии масштаба 1:2500000 (2014 г.) и Тектонической карте Арктики масштаба 1:5000000 (2019 г.), подготовленным в рамках международных проектов с участием геологических служб, университетов и академий наук 13 стран мира во Всероссийском научно-исследовательском институте им. А.П. Карпинского (ВСЕГЕИ). Охарактеризованы подходы к составлению этих карт, структуры и содержания легенд. Даны описания изобразительных средств и зарамочного оформления. Опыт, полученный при составлении тектонических карт Азии и Арктики, планируется применить при составлении Международной тектонической карты Азии масштаба 1:5000000 (ITMA-5000) и Тектонической карты России масштаба 1:2500000.

КЛЮчЕВЫЕ СЛОВА: Северная, Центральная и Восточная Азия; Арктика; тектоническая карта; принцип тектонического геокартирования

ФИНАНСИРОВАНИЕ: Исследования проведены в рамках Государственного задания Федерального агентства по недропользованию от 26.12.2019 № 049-00017-20-04.

\section{1. ВВЕДЕНИЕ}

Отечественной школой тектонического картографирования накоплен огромный опыт в составлении тектонических карт на крупные регионы мира. Уже с самого начала развития этого направления картографирования ведущее место в нем заняли советские и российские ученые. Так, первым президентом образованной в 1956 г. подкомиссии по тектоническим картам Комиссии по геологической карте мира (CGMW) при ЮНЕСКО стал директор Геологического института АН академик Н.С. Шатский. В дальнейшем президентами и генеральными секретарями этой подкомиссии традиционно становились академики и выдающиеся ученые Д.В. Наливкин, А.В. Пейве, В.Е. Хаин, Ю.Г. Леонов. Сегодня подкомиссию возглавляет академик А.И. Ханчук.

Работы по созданию тектонических карт традиционно проводились при тесном взаимодействии с созданной в 1960 г. подкомиссией по Северной Евразии (вначале подкомиссия по территории СССР), которую также возглавляли представители отечественной научной школы геологического картографирования Н.А. Белявский, члены-корреспонденты РАН Г.И. Горбунков, А.И. Жамойда, Ю.Е. Погребицкий. С 2004 г. вице-президентом подкомиссии по Северной Евразии является член-корреспондент РАН О.В. Петров, ее генеральным секретарем был С.П. Шокальский.

Главным результатом работы подкомиссии за последние годы стало создание двух тектонических карт Тектонической карты Северной, Центральной и Восточной Азии масштаба 1:2500000 и Тектонической карты
Арктики масштаба 1:5000000. Они составлены в рамках международных проектов по созданию атласов карт геологического содержания с участием геологических служб, университетов и академий наук России, Норвегии, Канады, Германии, Франции, Дании, США, Швеции, Великобритании, Китая, Кореи, Монголии и Казахстана [Petrov et al, 2016b, 2016c]. Тектоническая карта Арктики в 2019 г. была опубликована в Париже Комиссией по геологической карте мира [Petrov, Pubelye, 2019]. Paботы по созданию тектонических карт проводились во Всероссийском научно-исследовательском институте им. А.П. Карпинского (ВСЕГЕИ). Современные тектонические карты - это сложные многоуровневые ГИСпроекты, включающие слои с разнообразной геологогеофизической информацией по строению и тектонической эволюции земной коры. При этом их создание опирается на огромный опыт и вклад предшественников в разработку принципов тектонического картографирования, изложенных ниже.

\section{2. ИСТОРИЯ ВОПРОСА}

Тектоническое картографирование - одно из магистральных направлений научных исследований отечественных геологов. Начало тектонического картографирования территории России относится к 1933 г., когда А.А. Архангельским и Н.С. Шатским была опубликована первая цветная тектоническая схема СССР и Европы. Структурное районирование территории было проведено по принципу «возраста главной складчатости», который отвечает времени завершения геосинклинального 
развития и смены геосинклинального режима платформенным.

На этой основе в 1940-1970-х годах создана серия обзорных тектонических карт отдельных крупных стран и материков. В 1956 г. под редакцией академика Н.С. Шатского опубликована Тектоническая карта СССР масштаба 1:5000000, представленная на XX сессии МГК (Мехико, 1956 г.). В 1961 г. на ее основе подготовлена Тектоническая карта СССР масштаба 1:10000000 под редакцией Н.С. Шатского и А.А. Богданова (рис. 1), а в 1966 г. коллективом ВСЕГЕИ, под редакцией Т.Н. Спижарского, - Тектоническая карта СССР масштаба 1:7500000 (рис. 2).

Тектоническая карта СССР масштаба 1:5000000 явилась прототипом первой Международной тектонической карты Европы (1964 г.) под редакцией Н.С. Шатского, международных тектонических карт Америки (1969 г.), Африки (1978 г.), Австралии (1971 г.) и других территорий.

В 1966 г. коллективом Академии наук СССР под руководством Н.С. Шатского и А.Л. Яншина подготовлена Тектоническая карта Евразии масштаба 1:5000 000. На рис. 3 представлена составленная на ее основе Схематическая карта Евразии масштаба 1:20000000. В ходе работы над картой выявлены важнейшие глубинные разломы, впервые отмечено преобладание горизонтальных движений в образовании и развитии структур земной коры, различия в тектонической истории Тихоокеанского и Атлантического сегментов земной коры, дан тектонический анализ дна морей и океанов. Описание основных тектонических структур и их происхождение приведены в объяснительной записке к карте «Тектоника Евразии» [Yanshin, 1966].

В 1975 г. подготовлено, а в 1979 г. опубликовано второе издание Тектонической карты Европы и смежных областей масштаба 1:10000000 (отв. ред. В.Е. Хаин и Ю.Г. Леонов) (рис. 4). Объяснительная записка к карте на русском языке вышла из печати в 1978 г. [Khain, Leonov, 1978].

При составлении всех этих карт ведущим являлось районирование территорий по возрасту главной (завершающей, «платформообразующей») складчатости сучетом смены геосинклинальных формаций орогенными (молассы) и появления гранитных батолитов. Главный (завершающий) геосинклинальный комплекс на некоторых картах подразделен на отдельные структурные этажи, особо выделен «комплекс основания». На Тектонической карте СССР под редакцией Т.Н. Спижарского

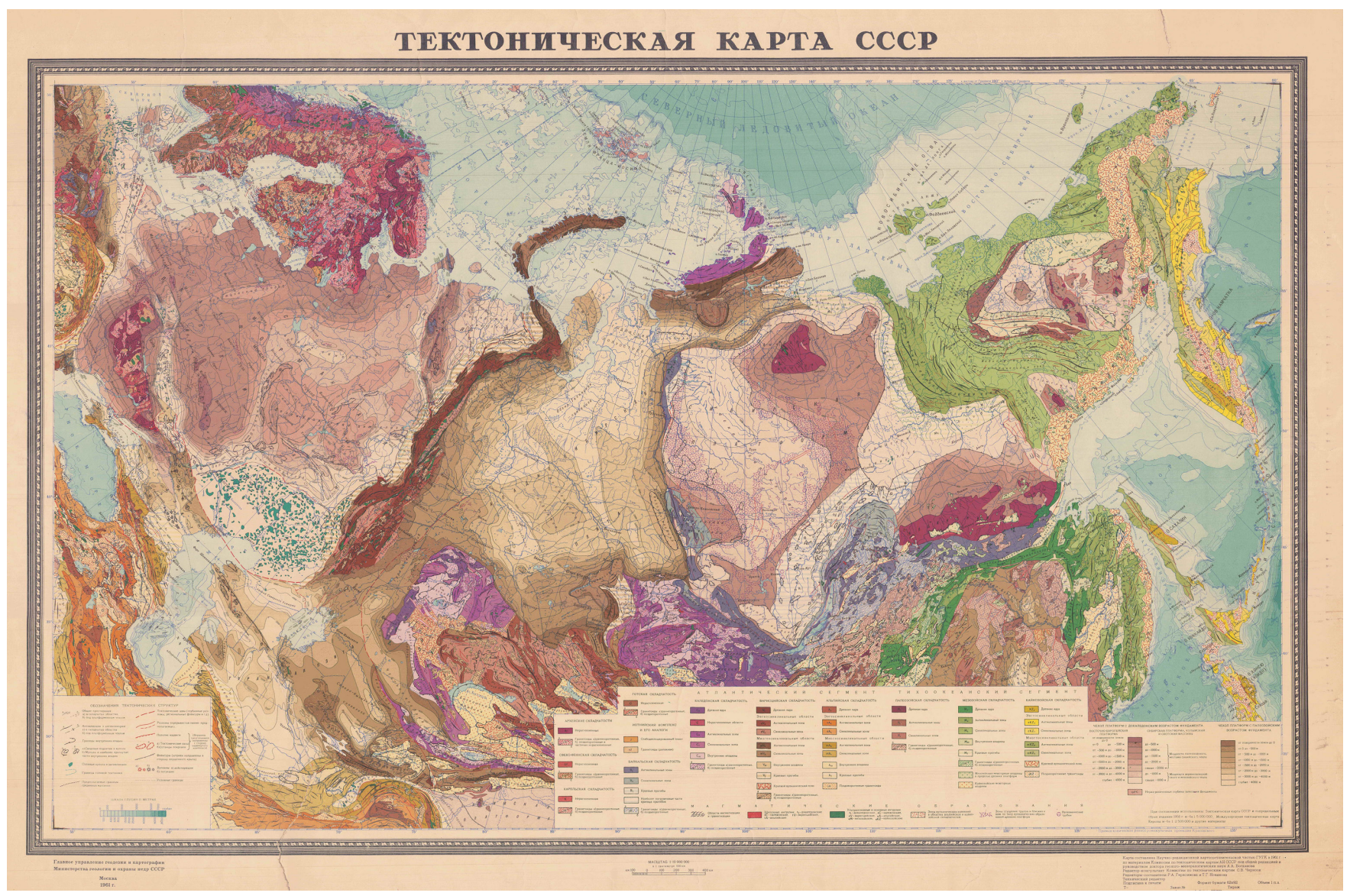

Рис. 1. Тектоническая карта СССР масштаба 1:10000000, редакторы Н.С. Шатский, А.А. Богданов, 1961 г. (составлена по Тектонической карте СССР масштаба 1:5000000, редактор Н.С. Шатский, 1956 г.).

Fig. 1. Tectonic Map of the USSR, scale: 1:10000000. Editors N.S. Shatsky and A.A. Bogdanov, 1961 (based on the Tectonic Map of the USSR, scale 1: 5000000 . Editor N.S. Shatsky, 1956). 
этажи отвечают определенным стадиям развития геосинклинали.

Во втором издании Тектонической карты Европы вместо структурных этажей применено расчленение складчатых комплексов по основным фазам деформаций, предшествующим завершающей складчатости и фактически соответствующим несогласиям, разграничивающим этажи. Расчленению подверглись также и комплексы основания, которые были разделены в соответствии с главными эпохами их деформаций. Штриховкой соответствующего цвета показана переработка комплексов основания в завершающую эпоху тектогенеза.

Для покрытых осадочным чехлом районов платформ использовался разработанный нефтяниками метод стратоизогипс. Предпочтение отдавалось изображению в изогипсах глубин залегания фундамента, оттенками основного цвета показывались разные ступени глубин. Цвет чехлов соответствовал возрасту фундамента (времени завершивших его формирование деформаций), иногда - возрасту осадочных комплексов чехла.

На картах отражался вещественный состав части структурных этажей в виде некоторых характерных формаций: моласс, флиша, орогенных вулканитов, платобазальтов (траппов), иногда спилит-диабазовой, спилит- кератофировой. Нашли отражение также дифференцированные по составу интрузивные массивы и фации метаморфизма для древних комплексов.

Слабой стороной тектонических карт с районированием по возрасту главной складчатости является отсутствие на них информации о процессах вещественного преобразования земной коры. Это явилось следствием того, что на составление карт во многом влияли, прежде всего, структурные, а не вещественно-формационные исследования.

Переломным моментом в тектонической картографии становится конец 60-х - начало 70-х годов прошлого столетия в связи с развитием учения об океанической коре геологического прошлого и ее преобразовании в континентальную [Peive, 1969]. Возникло представление об океанической, переходной (собственно геосинклинальной) и континентальной стадиях развития земной коры. Стало возможным различать такие стадии не только в современных обстановках, но и в геологическом прошлом, выделять комплексы горных пород, отвечающие различным стадиям этого процесса. Время становления континентальной коры определялось по появлению коллизионных гранитов и континентальных моласс. Такой подход представлял собой дальнейшее развитие тектонического районирования не столько по возрасту главной складчатости, сколько

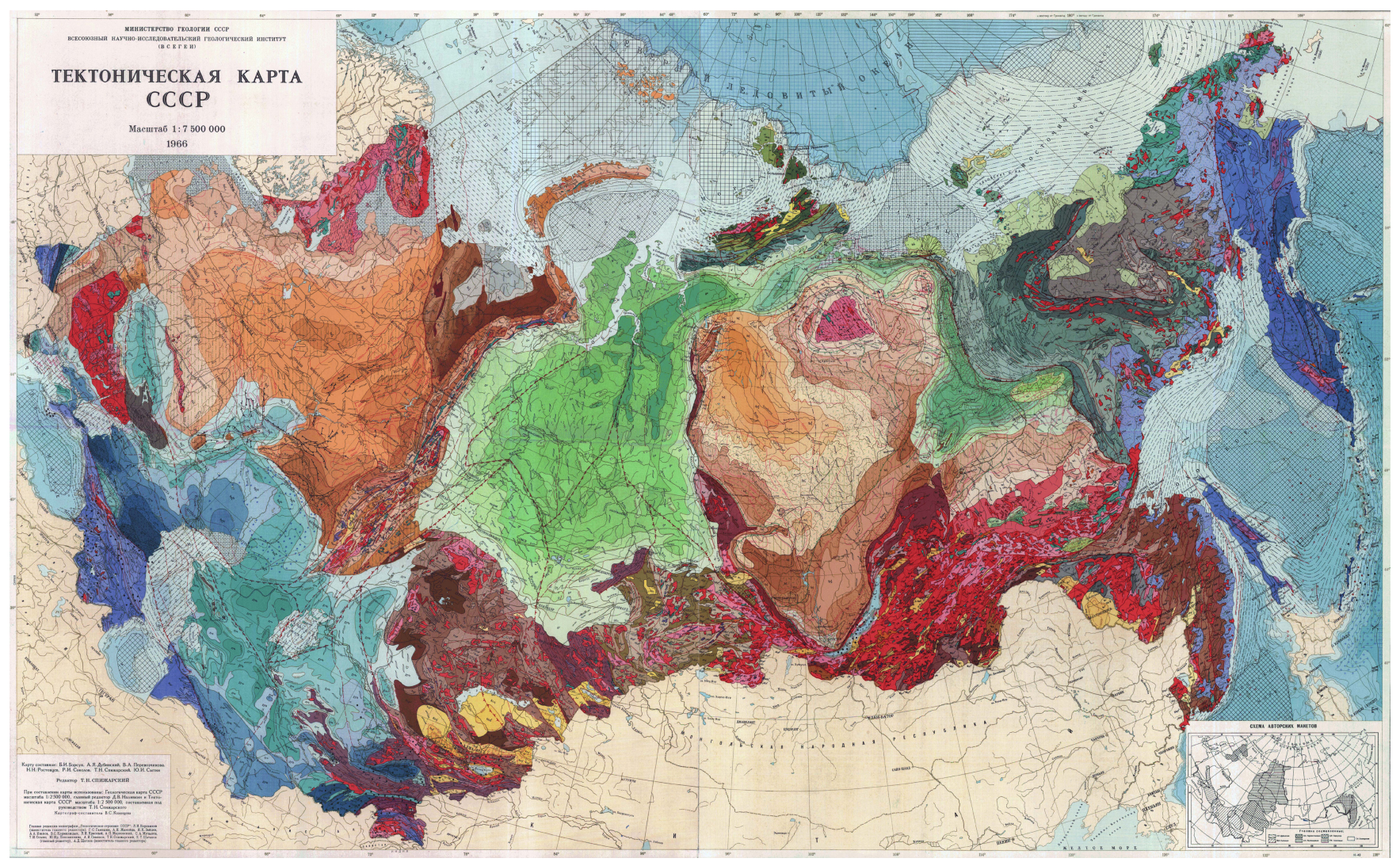

Рис. 2. Тектоническая карта СССР масштаба 1:7500000, редактор Т.Н. Спижарский, 1966 г. (составлена по Тектонической карте СССР масштаба 1:5000000, редакторы Н.С. Шатский, А.А. Богданов, 1961 г.).

Fig. 2. Tectonic Map of the USSR, scale 1:7500000. Editor T.N. Spizharsky, 1966 (based on the Tectonic Map of the USSR, scale 1:5000000. Editors N.S. Shatsky and A.A. Bogdanov, 1961). 
по времени преобразования океанической коры геологического прошлого в новообразованную континентальную кору.

Впервые эта идея была изложена А.В. Пейве и его соавторами в 1972 г. [Peive et al., 1972]. Почти одновременно в журнале «Геотектоника» были опубликованы две статьи, посвященные тектонической номенклатуре и классификации структурных элементов земной коры материков [Bogdanov et al., 1972] и принципам тектонического районирования океанов [Pushcharovsky, 1972]. А в 1976 г. опубликована обширная статья с подробным изложением принципов и основных результатов тектонического картографирования Северной Евразии на основе выделения разновозрастных областей формирования континентальной коры [Peive et al., 1976]. Статья сопровождалась схемой с отображением тектонических областей с континентальной корой, сформировавшейся в разное геологическое время, современных областей с незавершившимся формированием континентальной коры и океанов.

На базе этого подхода под руководством академиков А.В. Пейве и А.Л. Яншина в 1971-1978 гг. создана принципиально новая Тектоническая карта Северной Евразии масштаба 1:5000000, включившая территорию СССР, Западной Европы, смежные регионы Азии, акватории Арктики и дальневосточных морей (на рис. 5 представлена составленная на ее основе Тектоническая карта Северной Европы масштаба 1:20000000). Первая глава объяснительной записки к карте «Тектоника Северной Евразии» посвящена развернутой характеристике принципов составления тектонических карт по возрасту новообразованной континентальной коры [Peive, Yanshin, 1980].

В этот же период в связи с накоплением фактического материала стало возможным изображение тектоники дна океанов. Первой «океанской» картой явилась

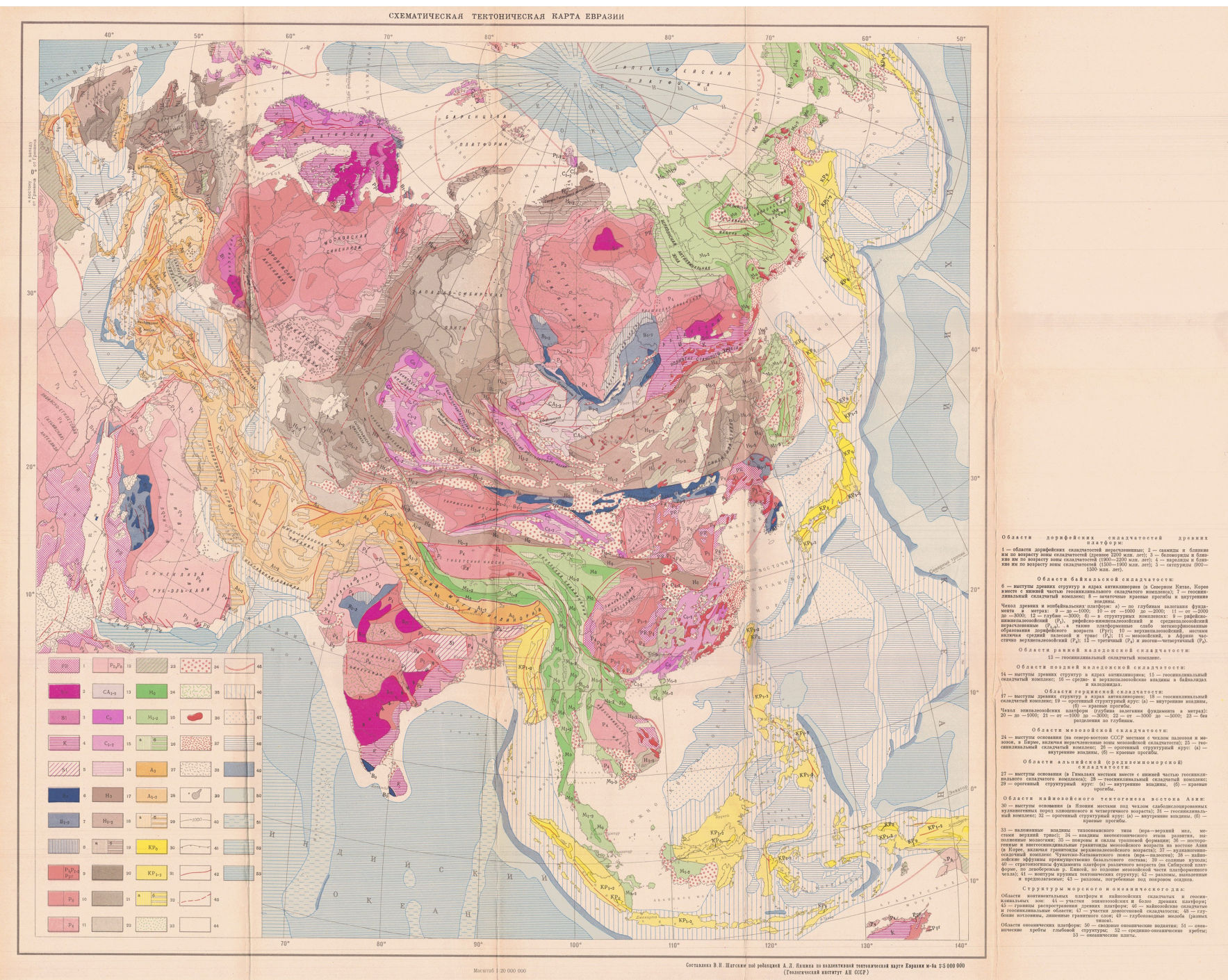

Рис. 3. Схематическая тектоническая карта Евразии масштаба 1:20000000, редактор А.Л. Яншин (составлена на основе Тектонической карты Евразии масштаба 1:5000000, 1966 г.).

Fig. 3. Schematic Tectonic Map of Eurasia, scale 1:20000000. Editor A.L. Yanshin (based on the Tectonic Map of Eurasia, scale 1:5000000, 1966). 
Тектоническая карта Тихоокеанского сегмента Земли под редакцией Ю.М. Пущаровского и Г.Б. Удинцева (1970 г.). Она была, по сути, структурно-геоморфологической, не содержала возрастных подразделений и не раскрывала историю океанической коры. Более информативными в этом отношении явились карты строения ложа океанов американского геолога Б.С. Хейзена с сотрудниками, составленные с использованием результатов глубоководного бурения и картирования линейных магнитных аномалий. Районирование на них проведено по возрасту подошвы осадочного слоя, обычно соответствующему и возрасту кровли второго, базальтового, слоя океанической коры. Изолиниями было показано изменение мощности осадочного чехла.

Принципы тектонического районирования по возрасту становления континентальной коры положены в основу первой международной Тектонической карты мира, подготовленной в 1980-х годах под эгидой подкомиссии тектонических карт Комиссии по геологической карте мира (CGMW) и под непосредственным руководством В.Е. Хаина и Ю.Г. Леонова. В 1984 г. карта издана в масштабе 1:15000000 и как настольный вариант) - в масштабе 1:45000000 (рис. 6).

Объяснительная записка к последней «Тектоника континентов и океанов» издана на английском и русском языках в 1988 г. [Leonov, Khain, 1988].

На карте выделены области с континентальной, океанической и переходной корой. На континентах показаны складчатые пояса и комплексы с подразделением по возрасту наиболее интенсивных, обычно завершающих деформаций, совпадающих с региональным метаморфизмом и гранитизацией, т.е. со становлением зрелой континентальной коры. Тем самым достигнуто совмещение традиционного принципа районирования по времени завершающей складчатости и нового принципа районирования по времени становления зрелой

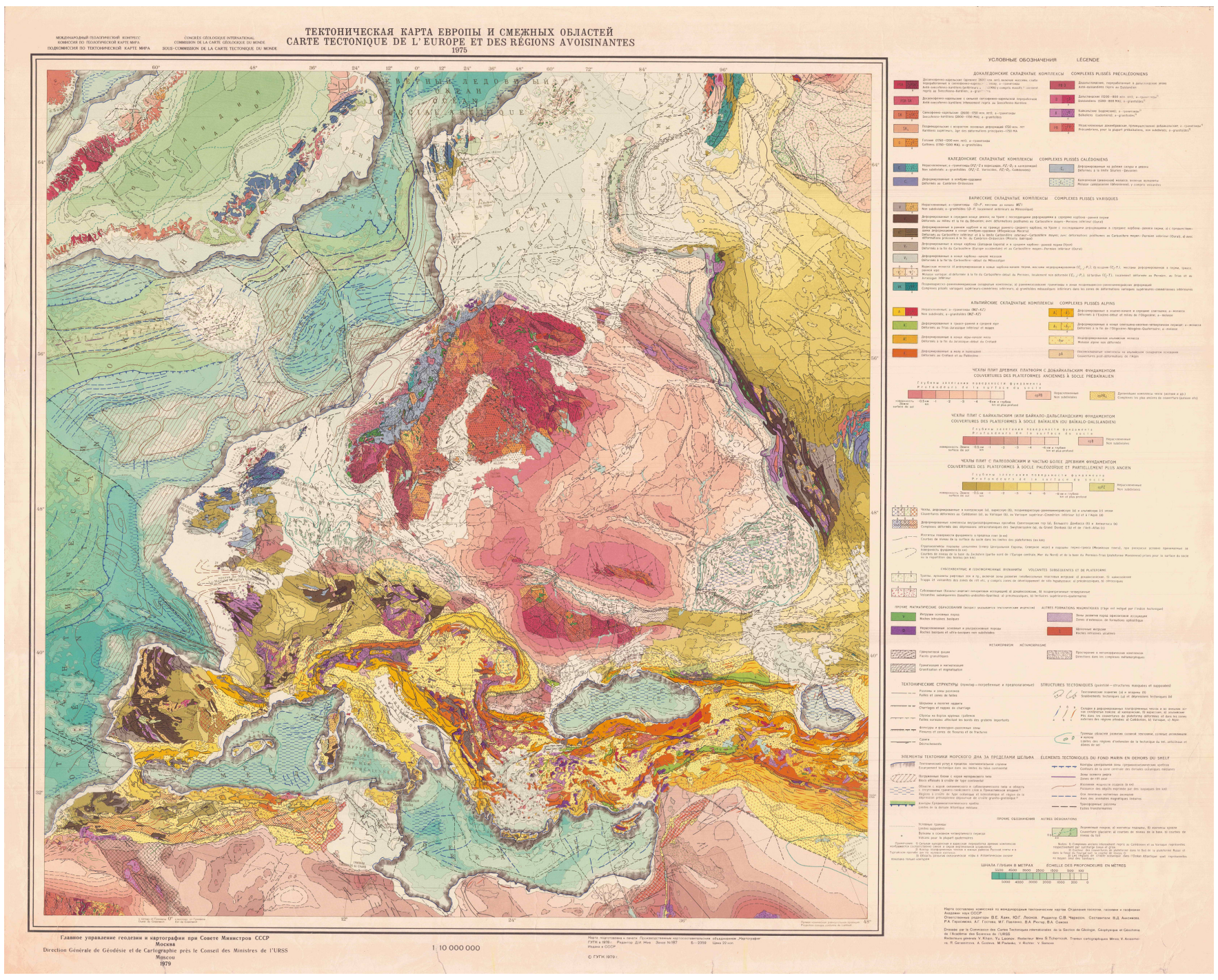

Рис. 4. Тектоническая карта Европы и смежных областей масштаба 1:10000000, отв. редакторы В.Е. Хаин и Ю.Г. Леонов, 1979 г. (составлена по Тектонической карте Европы масштаба 1:2500000).

Fig. 4. Tectonic Map of Europe and Adjacent Areas, scale 1:10000000. Chief Editors V.E. Khain and Yu.G. Leonov, 1979 (based on the Tectonic Map of Europe, scale 1:2500000). 
континентальной коры. Глобальное обобщение заставило авторов карты отказаться от обычного выделения эпох деформаций по их европейским названиям (каледонская, герцинская и другие) и выделить их в большем числе с чисто геохронологическими обозначениями (позднепалеозойская, раннемезозойская и т.п.).

В качестве самостоятельного класса структур на континентах цветом, соответствующим возрасту, и крапом показаны средне- и позднепалеозойские, мезозойские и кайнозойские орогенные (наложенные) впадины, вулканические пояса и ареалы, краевые прогибы. Отдельным цветом показаны выходы нерасчлененных складчатых и орогенных комплексов на современных шельфах.

В составе платформ цветом выделены доплитные (раннедокембрийские) образования древних платформ. Платформенные чехлы разделены на два типа - фанерозойские древних и верхнепалеозозойско-мезозойско-кайнозойские молодых платформ. Изопахитами и насыщенностью цвета отображена мощность, цветной штриховкой - позднепалеозойские, мезозойские и кайнозойские структурные деформации чехлов. Цветным крапом показаны ареалы траппового магматизма.
Полосчатая закраска предусмотрена для платформенных чехлов (фанерозойских и верхнепалеозойско-мезозойско-кайнозойских) на шельфе.

В областях с переходной корой коричневым цветом выделены вулканические и невулканические островные дуги, диагональной сиреневой закраской - междуговые бассейны.

Океаническая кора расчленена по возрасту с обособлением внутренних $\left(\mathrm{N}_{2}-\mathrm{Q}\right)$ и фланговых $\left(\mathrm{P}_{2}-\mathrm{N}_{1}\right)$ зон срединно-океанических хребтов и изображением их осей. Изолиниями показано изменение мощности осадочного чехла.

Карта включала Циркумполярную карту-врезку Арктики, на которой впервые были отмечены все тектонические элементы не только суши, но и акватории Северного Ледовитого океана и Северной Атлантики. В дальнейшем именно эта карта стала основой для нового проекта CGMW «Тектоническая карта Циркумполярной Арктики масштаба 1:5000000», заявленного в 2004 г. и реализованного в 2019 г.

Дальнейшее развитие представлений о структуре и преобразовании земной коры и литосферы в целом заставило переосмыслить концепцию превращения

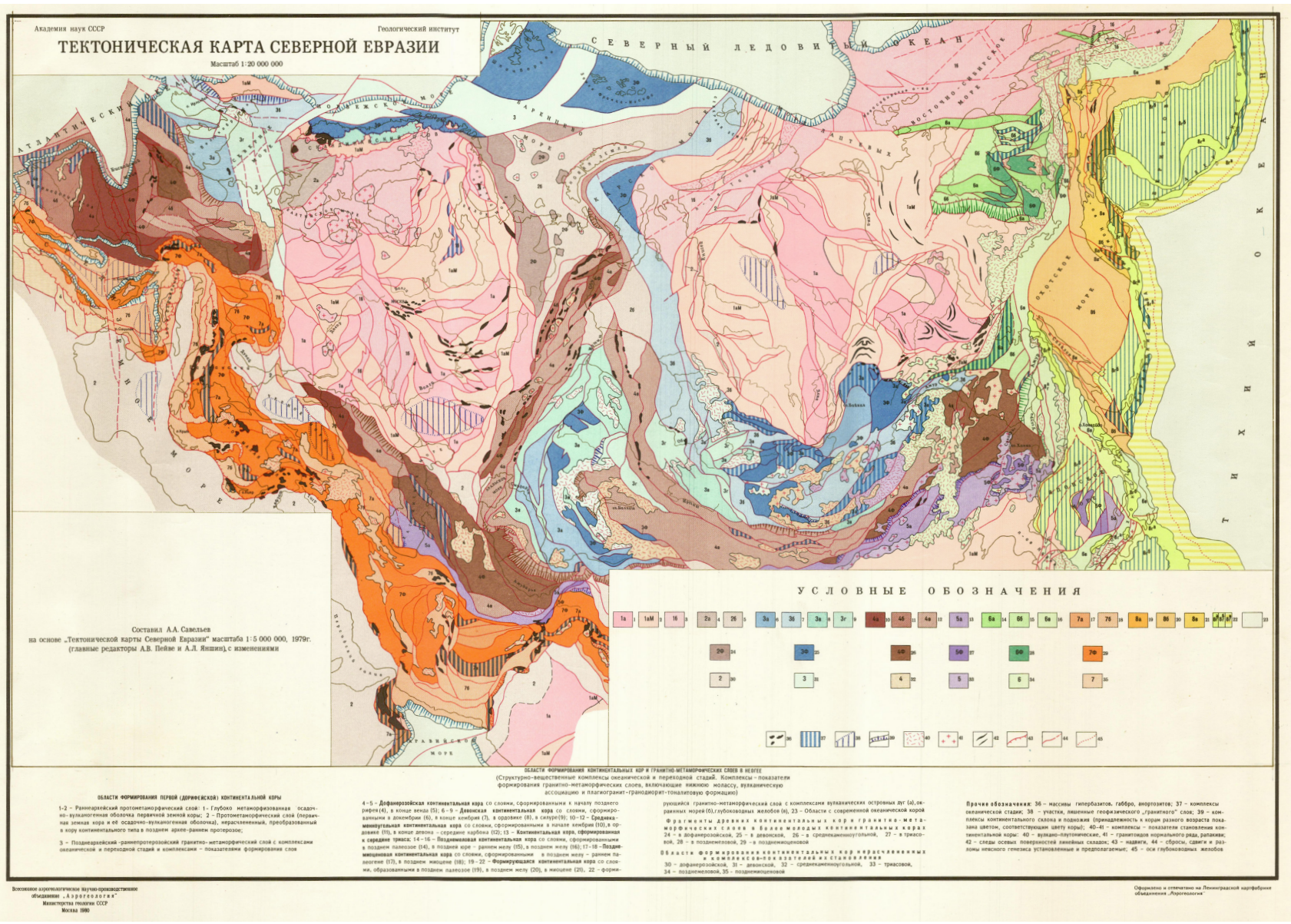

Рис. 5. Тектоническая карта Северной Евразии. Масштаб 1:20000 000, 1980 г. (составлена на основе Тектонической карты Северной Евразии масштаба 1:5000000, редакторы А.В. Пейве, А.Л. Яншин, 1979 г.).

Fig. 5. Tectonic Map of Northern Eurasia, scale 1:20000000, 1980 (based on the Tectonic Map of Northern Eurasia, scale 1:5000000. Editors A.V. Peive and A.L. Yanshin, 1979). 
океанической коры в континентальную. Исследования последних лет показали, что континентальная кора, как и переходная и даже океаническая, является полигенной, т.е. в своей истории претерпела неоднократную структурно-вещественную переработку и постоянно меняла свои геолого-геофизические свойства. Эти разновидности полигенной коры слагают единую оболочку Земли с определенными свойствами, выделяемую в качестве консолидированной коры.

Под консолидированной корой понимается оболочка, имеющая подошву и кровлю, претерпевшая (частично или полностью) складчатость, метаморфизм и гранитизацию и отличающаяся по вещественному составу, строению и физическим параметрам от перекрывающих (плитный чехол) и подстилающих (породы верхней мантии) образований литосферы [Leonov M.G., Leonov Yu.G., 2002].

Этапы консолидации земной коры, геологические формации различных геодинамических обстановок формирования консолидированной коры и ее структурно-вещественная переработка в процессе эволюции являются основополагающими принципами создания тектонических карт нового поколения начиная с середины 90-х годов прошлого столетия. На них отражаются: (1) возраст консолидации коры (по характерным геологическим комплексам), (2) главнейшие осадочные и вулканогенные формации доконсолидационного развития коры, (3) офиолитовые комплексы в их современном состоянии, (4) интрузии и, в первую очередь, гранитоиды различных геодинамических обстановок

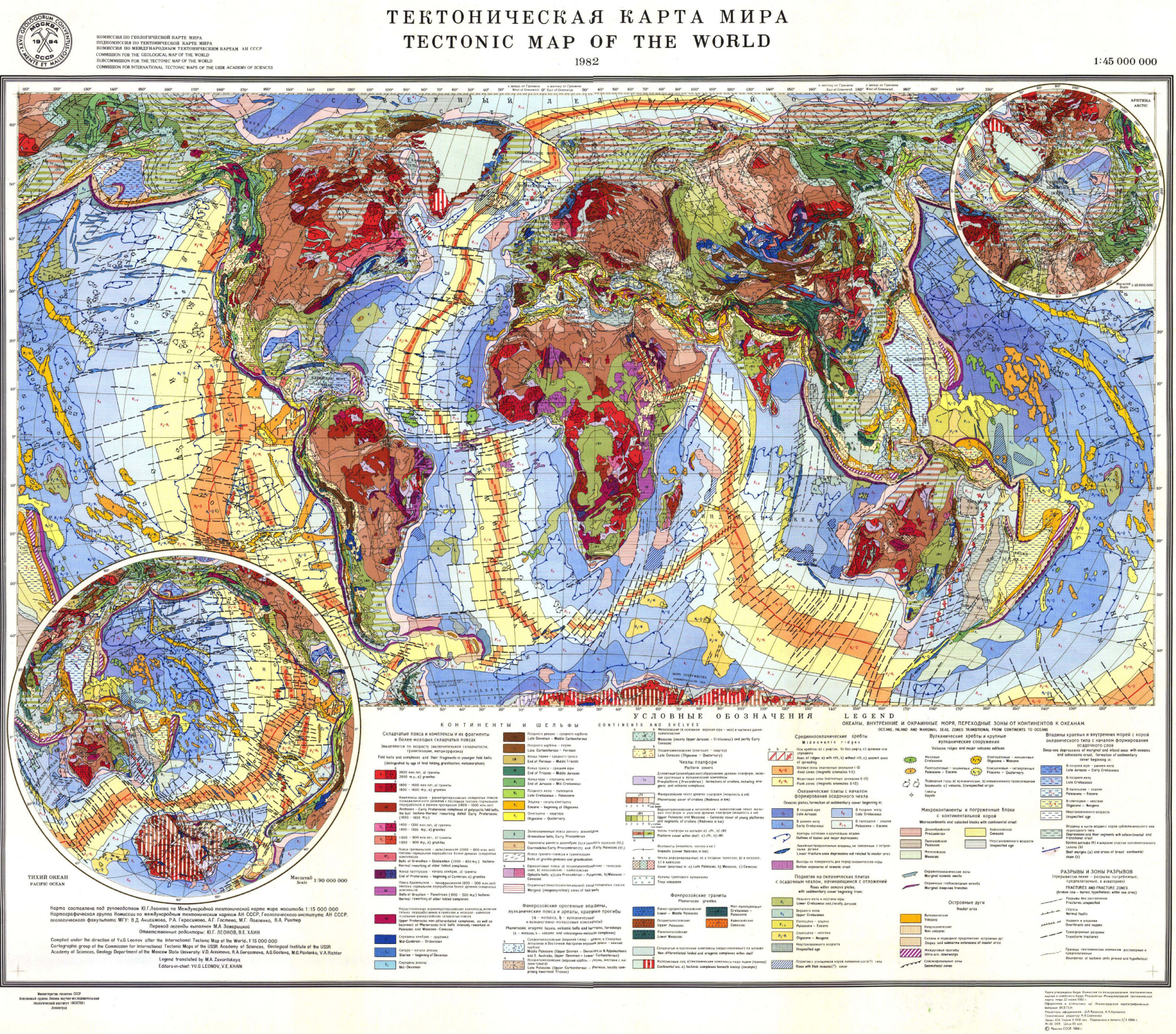

Рис. 6. Тектоническая карта мира масштаба 1:45000000, отв. редакторы Ю.Г. Леонов, В.Е. Хаин, 1984 г. (составлена по Международной тектонической карте мира масштаба 1:15000 000, 1984 г.).

Fig. 6. Tectonic Map of the World, scale 1:45000000. Chief editors Yu.G. Leonov and V.E. Khain, 1984 (based on the International Tectonic Map of the World, scale 1:15000000,1984). 
(надсубдукционные, коллизионные, постколлизионные и другие), (5) проявленность регионального метаморфизма и отдельных метаморфических фаций, (6) молассовые образования. Отдельно показывается кора, структурно-термально переработанная в более поздние этапы.

Создаваемые на этой основе карты являются органичным продолжением карт, отражающих процесс превращения океанической коры в континентальную. Выделение этапов и комплексов-показателей консолидации позволяет представить весь историко-тектонический процесс изменения и наращивания земной коры и ее сегментов как в вертикальном, так и в латеральном направлении, при этом основным критерием выделения блоков континентальной коры является время ее консолидации.
С понятием «консолидированной коры» связана выработка различных подходов к отображению складчатых поясов, складчатых и метаморфических фундаментов платформ с одной стороны и осадочных чехлов (плитных комплексов) - с другой. Если районирование первых проводится по времени консолидации континентальной коры, то основным принципом отображения плитного комплекса является возраст самых нижних горизонтов и его мощность.

Эти тенденции тектонической картографии впервые были реализованы в 3-м издании Международной тектонической карты Европы масштаба 1:5000000 (1996 и 1998 гг.), составленной под редакцией В.Е. Хаина и Ю.Г. Леонова [Khain et al., 1998] и представленной в 2000 г. на XXXI сессии МГК (Рио-де-Жанейро) (рис. 7). По научному содержанию и оформлению она

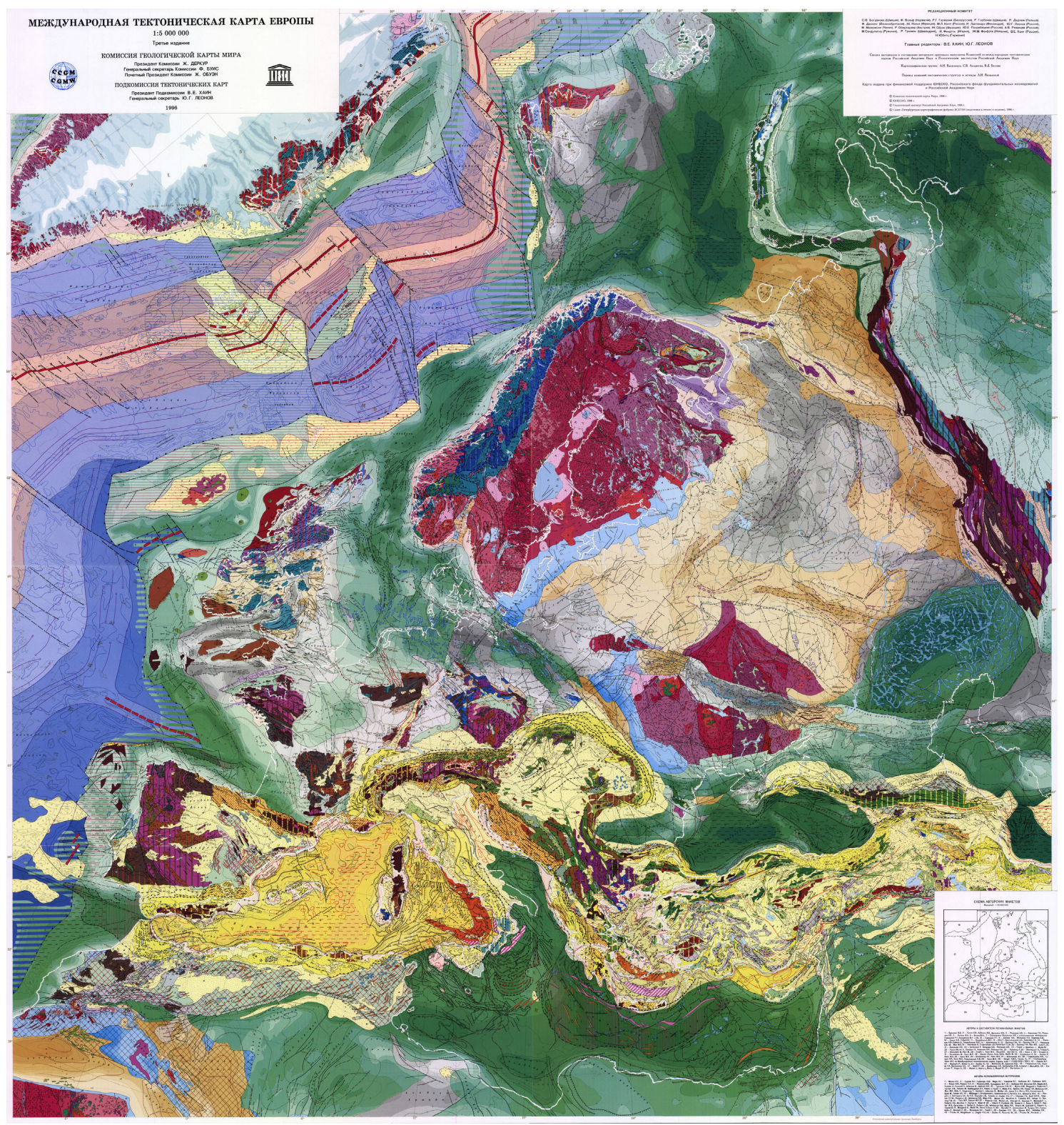

Рис. 7. Тектоническая карта Европы масштаба 1:5000000, редакторы В.Е. Хаин, Ю.Г. Леонов, 1998 г.

Fig. 7. Tectonic Map of Europe, scale 1:5000000. Editors V.E. Khain and Yu.G. Leonov, 1998. 
была признана эталоном тектонических карт для континентов.

Легенда к карте включала деление тектонической истории Земли на большое количество фаз и этапов, которые соответствовали предполагаемым эпохам консолидации коры. Дробное деление тектонических циклов вызвало необходимость разработки новой цветовой шкалы для тектонических событий. Были применены также новые принципы показа внутренней структуры платформенных чехлов и осадочных комплексов бассейнов. Большим достижением карты было отображение архейско-мезопротерозойской истории формирования фундамента Восточно-Европейской платформы.

\section{3. ТЕКТОНИЧЕСКАЯ КАРТА СЕВЕРНОЙ, ЦЕНТРАЛЬНОЙ И ВОСТОЧНОЙ АЗИИ И СОПРЕДЕЛЬНЫХ ТЕРРИТОРИЙ МАСШТАБА 1:2500000}

Апробированные в Международной тектонической карте Европы принципы, легенда и изобразительные средства с успехом использовались при создании серии более поздних тектонических карт. В частности, они были положены в основу тектонических исследований в международных проектах России, Китая, Монголии, Казахстана и Республики Корея, завершившихся изданием в составе «Атласа геологических карт Северной, Центральной и Восточной Азии масштаба 1:2500000» под ред. Ю.Г. Леонова и О.В. Петрова Тектонической карты Центральной Азии и сопредельных территорий масштаба 1:2500000 [Petrov et al., 2008] и Тектонической карты Северной, Центральной и Восточной Азии и сопредельных территорий масштаба 1:2500000 [Petrov et al., 2014b] с объяснительной запиской [Petrov et al., $2014 \mathrm{a}]$ (рис. 8). Тектоническая карта Центральной Азии была представлена в 2008 г. на 33-й сессии Международного геологического конгресса в г. Осло (Норвегия), а тектоническая карта на расширенную территорию Северной, Центральной и Восточной Азии - в 2012 г. на 34-й сессии МГК в г. Брисбене (Австралия).

Легенда для этих карт по сравнению с легендой к карте Европы в связи с изменением масштаба исследований расширена и дополнена, включает возрастной, литологический и структурно-тектонический блоки (рис. 9).

Возрастной блок (рис. 10) состоит из двух частей легенды для складчатых поясов и фундаментов платформ и легенды для платформенных чехлов. В левой части блока представлена шкала орогенических тектонических событий (аккреционных и коллизионных), приводящих к росту или структурно-термальной переработке ранее сформированной континентальной земной коры (отражаются цветом времени их проявления в соответствии с цветовой возрастной шкалой). В его правой половине приведены изобразительные средства для чехлов платформ. Выделено семь генераций осадочных палеобассейнов, каждой из которых соответствует своя цветовая шкала.
Цвет отражает время начала формирования чехла, а оттенками и изопахитами показана мощность отложений.

В литологическом блоке легенды предусмотрен крап для отображения состава характерных (диагностических) геологических комплексов, фиксирующих те или иные тектонические (геодинамические) обстановки (рис. 11). Выделена ассоциация магматических и осадочных комплексов палеоокеанической коры (офиолиты, кремнисто-базальтовые и осадочные комплексы первого и второго слоев палеоокеанической коры), сохранившаяся в виде сутурных офиолитовых зон. Другие группы пород представлены вулканическими, вулканогенно-осадочными, осадочными и интрузивными комплексами, отражающими обстановки активных континентальных окраин западно-тихоокеанского и андского типа, коллизии, внутриплитного магматизма и пассивных континентальных окраин.

Среди интрузивных образований выделены граниты М-типа (островные дуги) и І-типа (островные дуги, вулканоплутонические пояса и коллизионные зоны), S-граниты коллизионных зон, А-граниты вулканоплутонических поясов и постколлизионных обстановок, редкометалльные лейкограниты и щелочные ассоциации. Интрузии основного и ультраосновного состава представлены дунит-клинопироксенит-габбровой формацией (зональные массивы урало-аляскинского типа с платиноидной, Fe, Ti, V минерализацией), перидотит-габбровыми дифференцированными массивами норильского типа с $\mathrm{Ni}-\mathrm{Cu}$ и платиноидным оруденением, клинопироксенит-анортозит-лейкогаббровой формацией с Fe, Ti, V минерализацией, щелочными габброидами и ультраосновными породами.

Предусмотрено также выделение флишевых, молассовых и метаморфических комплексов. Последние представлены «серыми гнейсами» древнейших ядер кратонов, гранулит-гнейсовыми, амфиболит- и гранитогнейсовыми комплексами фундаментов кратонов и микроконтинентов, гнейсогранитовыми и мигматитовыми HTLP-комплексами внутриконтинентальных термальных зон и куполов, HPLT-комплексами голубых сланцев и эклогитов.

Структурно-тектонический блок легенды включает условные знаки для обозначения структурно и термально переработанных комплексов, разломов различной кинематики, вулканоструктур, соляной тектоники, гранитогнейсовых куполов, зон смятия и меланжей, других структурных элементов.

В легенде к Тектонической карте Северной, Центральной и Восточной Азии сделан акцент на отражении конструктивной аккреционно-коллизионной тектоники литосферы. Именно эти процессы отвечают за формирование консолидированной коры, они же предопределили структуру и границы планетарных подвижных поясов, входящих в состав исследованной территории: Центрально-Азиатского (Урало-Монгольского), Тетического и Тихоокеанского. В истории формирования коры Северной, Центральной и Восточной 
Азии выделено шесть основных этапов консолидации (от палеопротерозойского до позднемезозойско-кайнозойского).

Наряду с этим, на всех этапах тектонической эволюции литосферы имели место прямо противоположные по своей направленности процессы мантийного апвеллинга, сопряженные с глубокими расколами континентальной коры вплоть до образования новой океанической коры, возникновением зон высокого прогрева и декомпрессии, внедрением в кору глубинного мантийного вещества и активным взаимодействием мантийных флюидов с сиалическим веществом коры. Эти процессы приводили к деструкции ранее сформированной континентальной коры и новообразованию

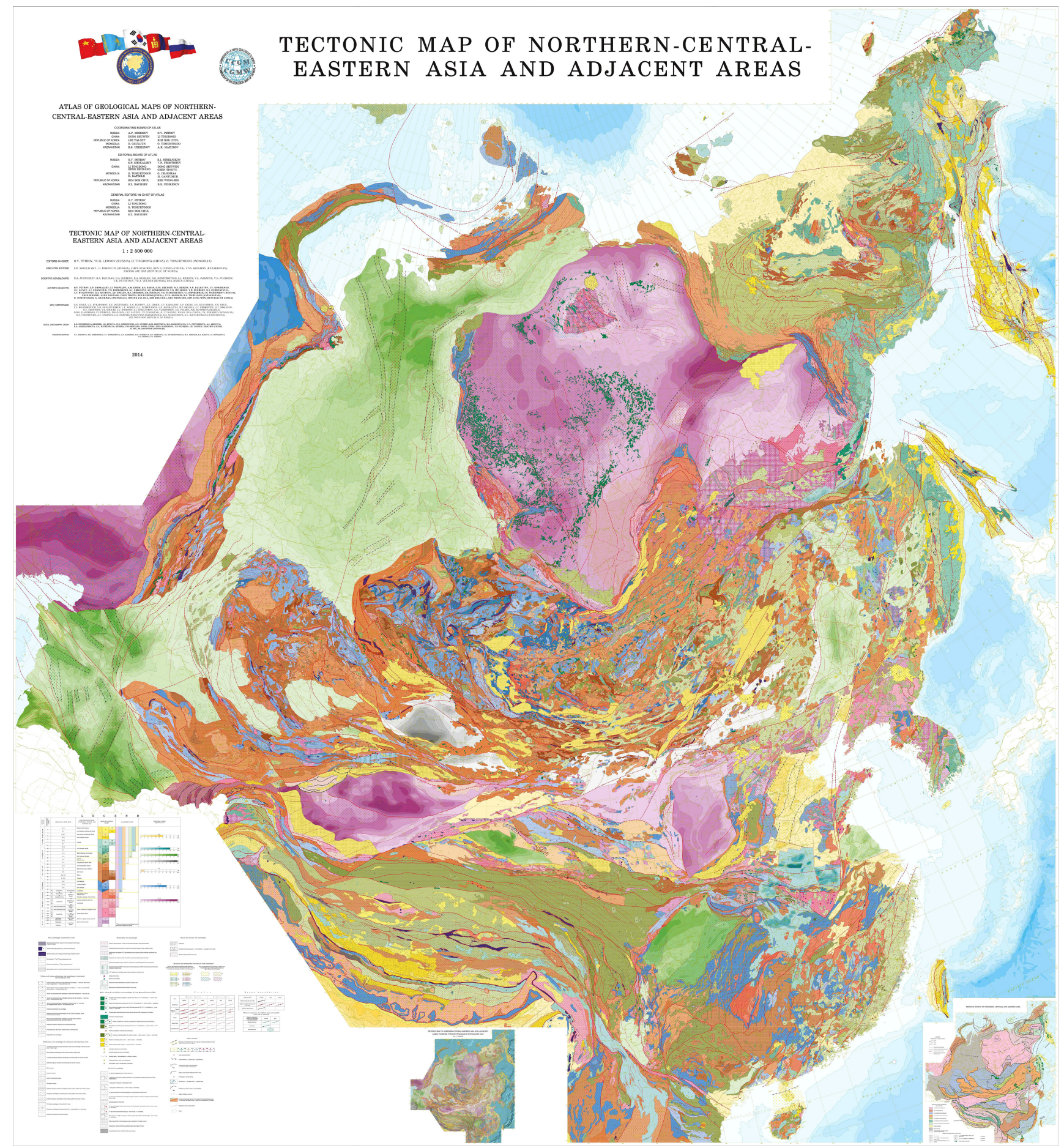

Рис. 8. Тектоническая карта Северной, Центральной и Восточной Азии и сопредельных территорий масштаба 1:2500 000, редакторы О.В. Петров, Ю.Г. Леонов, Ли Тингдонг, О. Томуртогоо, 2014 г.

Fig. 8. Tectonic Map of North, Central and East Asia and Adjacent Areas, scale 1:2500000. Editors O.V. Petrov, Yu.G. Leonov, Li Tingdong, 0. Tomurtogoo, 2014. 

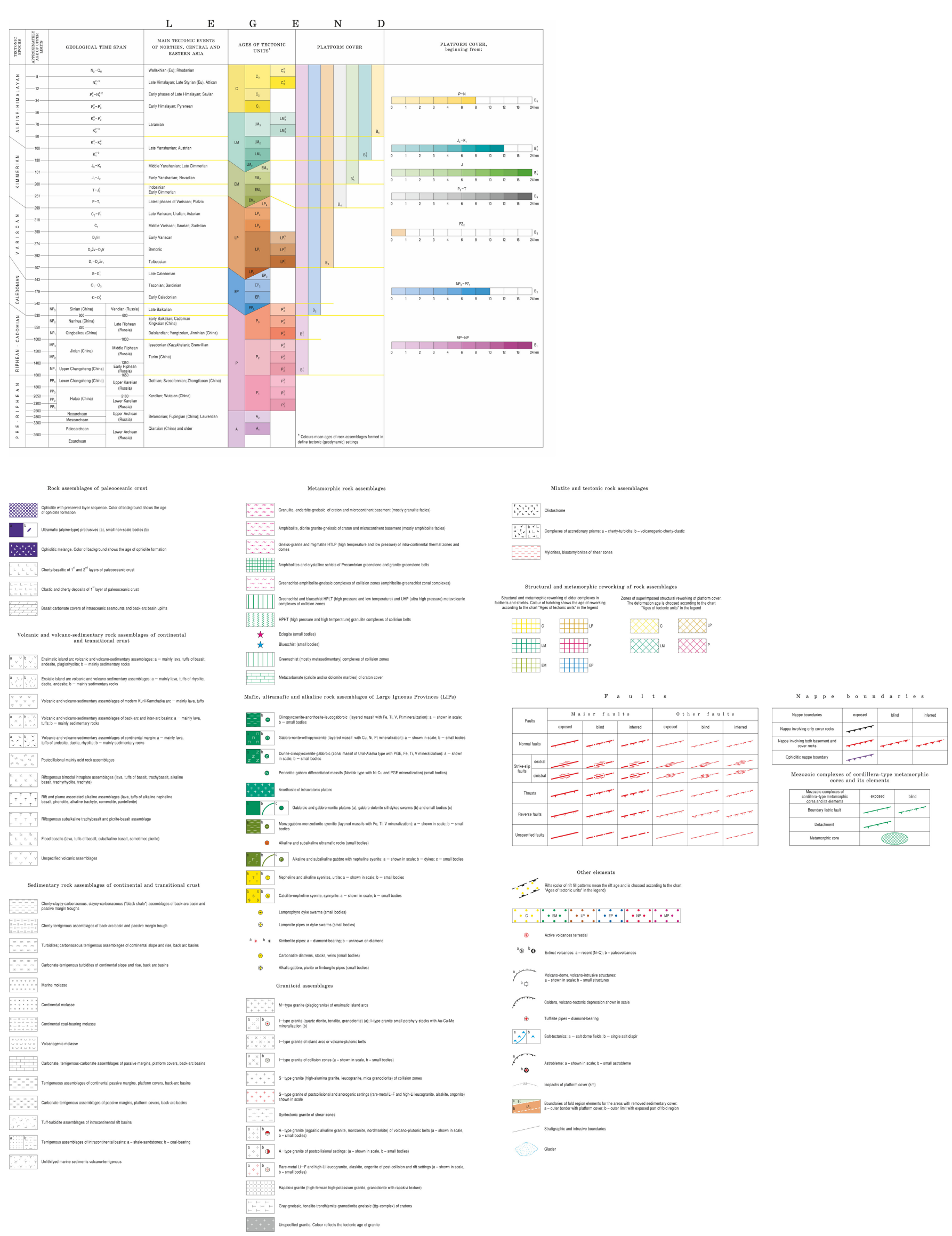

Рис. 9. Легенда к Тектонической карте Северной, Центральной и Восточной Азии и сопредельных территорий масштаба 1:2500000 (см. рис. 8).

Fig. 9. Legend of the Tectonic Map of North, Central and East Asia and Adjacent Areas, scale 1:2500000 (see Fig. 8). 


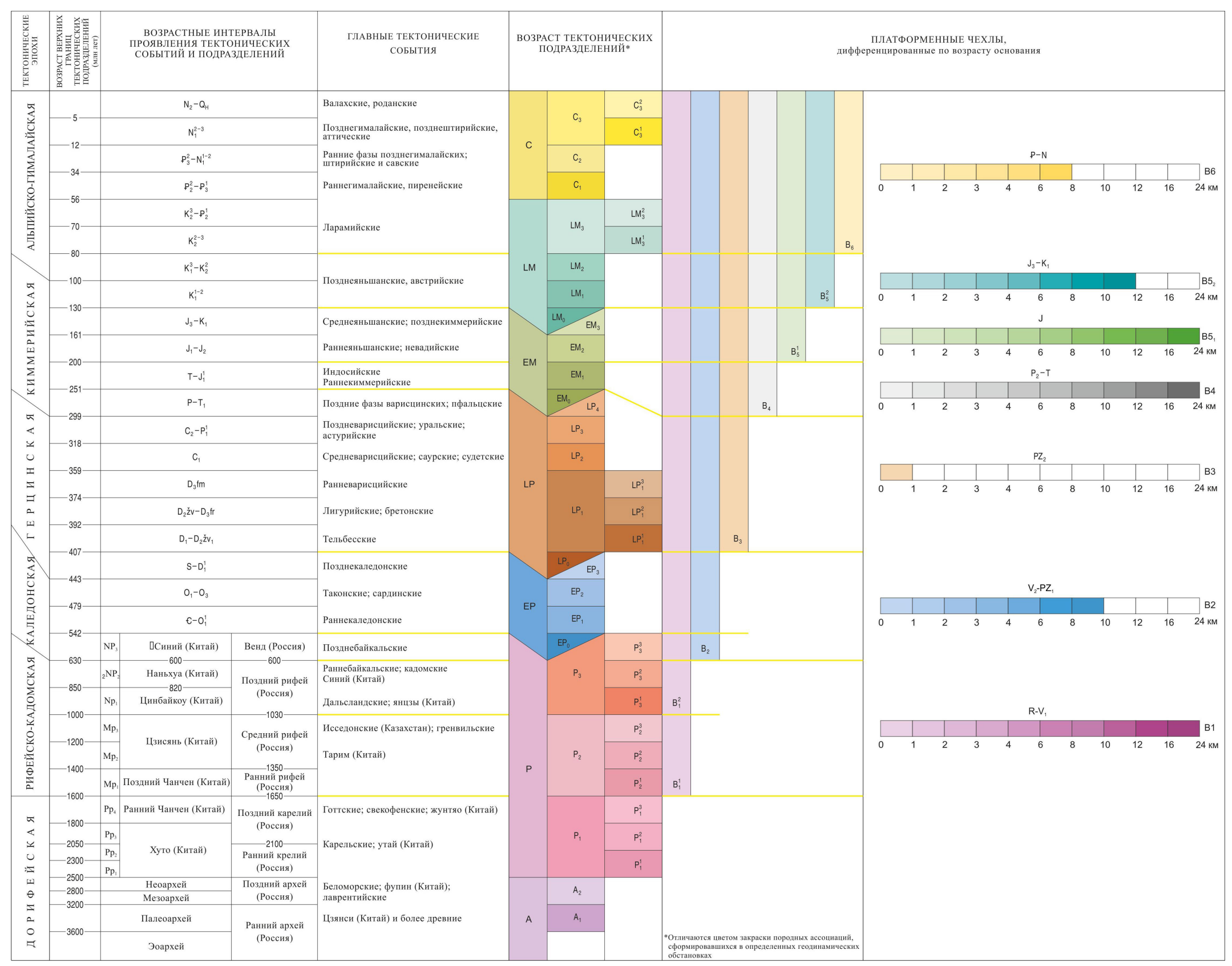

Рис. 10. Возрастной блок легенды к Тектонической карте Северной, Центральной и Восточной Азии и сопредельных территорий масштаба 1:2500000 (см. рис. 8). Fig. 10. Age data for the Tectonic Map of North, Central and East Asia and Adjacent Areas, scale 1:2500000 (see Fig. 8). 
Магматические и осадочные комплексы палеоокеанической коры

\begin{tabular}{|c|c|}
\hline & Офиолитовые (с сохранившейся последовательностью слоев) \\
\hline & амафические (альпинотипные) протрузивные массивы (а), малые внемасштабные тел \\
\hline & Офнолитовые меланжи \\
\hline & Кремнисто-базальтовые первого и второго слоев палеоокеанической коры \\
\hline & Обломочные и кремнистые осадочного чехла, с участием базальтов и карбонатных пород \\
\hline & Базалттово-карбонатные чехлов симаунтов и поднятий в задуговых бассейнах \\
\hline & $\begin{array}{l}\text { וканические и вулканогенно-осадочные комплексы переходной и } \\
\text { континентальной коры }\end{array}$ \\
\hline & 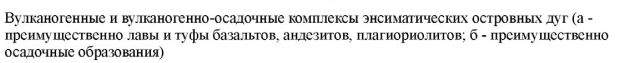 \\
\hline & 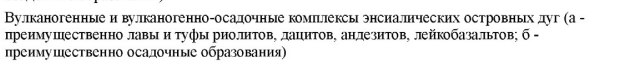 \\
\hline & 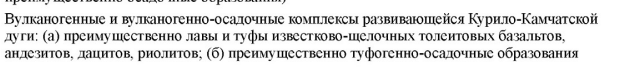 \\
\hline & 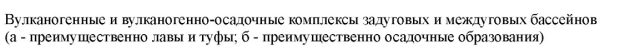 \\
\hline & 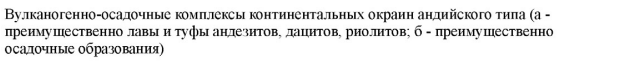 \\
\hline & Вулканогенные постколлизионные пояса и вулканические дуги \\
\hline & $\begin{array}{l}\text { Бимодальные вулканогенно-осадочные рифтогенные комплексы (лавы н туфы базальтов, } \\
\text { трахибазальтов, щелочных базальтов, риолитов, трахирнолитов, трахитов) }\end{array}$ \\
\hline & 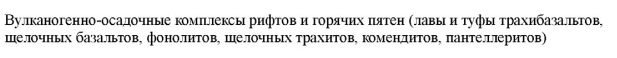 \\
\hline & Платобазальтовыс комплексы (лавы н туфы базальтов, трахибазальтов, пикритов) \\
\hline & $\begin{array}{l}\text { Трахиббазалтт-базалтовые, пикрит-базальтовые континентальные рифтогенные и } \\
\text { внутриплитныс оксанические комплкксы ОВВ }\end{array}$ \\
\hline & vплекссы неу \\
\hline
\end{tabular}

Осадочные комплексы переходной и континентальной коры

\begin{tabular}{|c|c|}
\hline & $\begin{array}{l}\text { Кремнисто-глинисто-углеродистыс, глинисто-углеродистые (чсрносланцевыс) задуговых } \\
\text { бассейнов и прогибов пассивных окраин }\end{array}$ \\
\hline & $\begin{array}{l}\text { Кремнисто-терригенные задуговых басссйнов и прогибов пассивных окраин и } \\
\text { платформенных чехлов }\end{array}$ \\
\hline & $\begin{array}{l}\text { Терригенные флишевые углеродистые тонтинентальных склонов и подножий, краевых } \\
\text { прогибовв, задуговых бассейнов }\end{array}$ \\
\hline & $\begin{array}{l}\text { Карбонатно-терригенные флишевые и флишоидные континентальных склонов и подножиі } \\
\text { красых прогибов, задуговых басссйнов }\end{array}$ \\
\hline & Молассовые морские \\
\hline & Молассовые континентальные \\
\hline & Молассовые континентальные угленосные \\
\hline & Молассовые вулканогенные \\
\hline & $\begin{array}{l}\text { Карбонатные и терригенно-карбонатные шельфовые отложения чехлов платформ, } \\
\text { пассивных континентальных окраин и залуговых бассейнов активных континентальных } \\
\text { окраин }\end{array}$ \\
\hline & $\begin{array}{l}\text { Tерритенные отложения чехлов плаафформ, пассивных континенттальных окраин и задуговых } \\
\text { бассейнов активных континентальных окраин }\end{array}$ \\
\hline & $\begin{array}{l}\text { Карбонатно-терригенныс отложсния чехлов платформ, пассивных континентальных окраин } \\
\text { и задуговых басссйнов активных конттинсттальных орраин }\end{array}$ \\
\hline & Туфо-терригенные внутриконтинентальных рифтовых бассейнов \\
\hline & $\begin{array}{l}\text { Tерригенные (а) и терригенные угленосные (б) внутриконтинентальных осадочных } \\
\text { бассейнов }\end{array}$ \\
\hline & 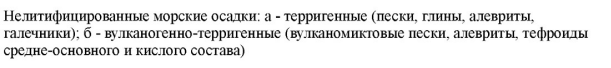 \\
\hline & Метаморфические комплексы \\
\hline & 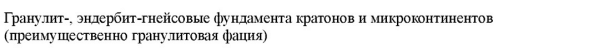 \\
\hline & $\begin{array}{l}\text { Амфиболиты, диорито-, гранито-гнейсы фундамента кратонов и микроконтинентов } \\
\text { (прекмущественно амфиболитовая фациил) }\end{array}$ \\
\hline & $\begin{array}{l}\text { Гнейсо-гранитовые и митиматитовые НTLP (высокогемпературные низкобарические) } \\
\text { внутриконттнентталььых термальных зон и куполов }\end{array}$ \\
\hline & $\begin{array}{l}\text { Комплексы амфиболитов, коматиитов и кристаличческих сланцев докемборийскких } \\
\text { зеленокаменных и гранит-зеленокаменных поясов }\end{array}$ \\
\hline & $\begin{array}{l}\text { Зеллносланцсво-амфиболит-гнсйсовыс коллизионных зон (амфиболит-зелсносланцсвыс } \\
\text { зональные комплексы) }\end{array}$ \\
\hline & гемператур) коллизионных зон и офнолитовых сутур \\
\hline
\end{tabular}

\section{Метаморфические комплексы}

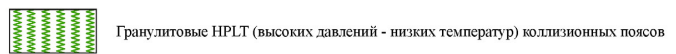

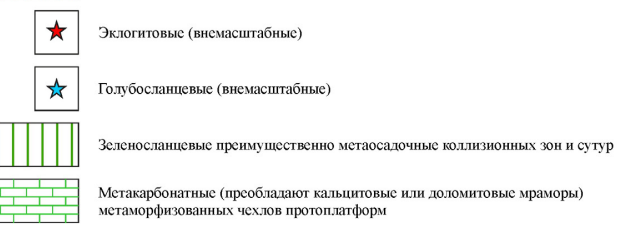

Интрузивные комплексы пород основного, ультраосновного и щелочного состава крупных магматических провинций

\begin{tabular}{ll} 
млинопироксенит-анортозит-лейкогаббровые (расслоенные массивы с Fe, Ti, V и Pt \\
\hline$-=-\mathrm{b}$
\end{tabular}

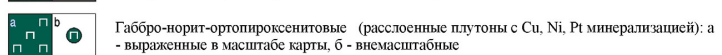

${ }^{2} z z^{2}$
$z$

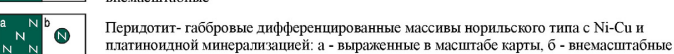

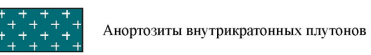

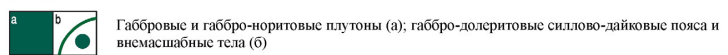

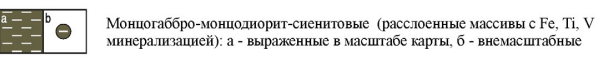

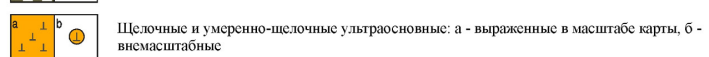

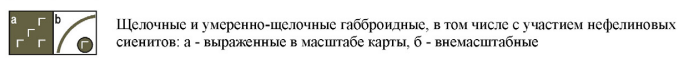

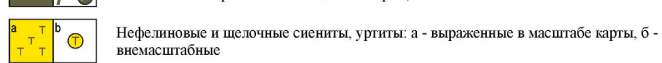

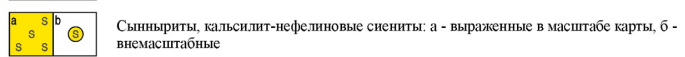

$\Theta \quad$ Лампрофиры: внемасштабнныс дайковые рои и поля

^ Л Лампроиты: внемасштаб̆ысе дайковые рои и поля

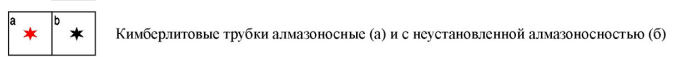

(®) Диятремы, суббвулканические штоки карбонатнтов (внемасштаб̆ные тела)

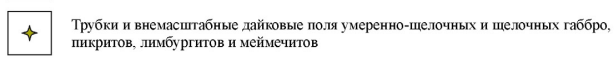

Гранитоидные комплексы

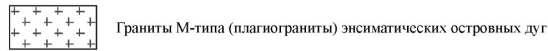

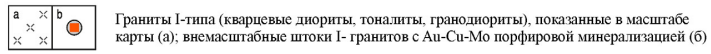

\begin{tabular}{ll}
\hline$x \cdot x \cdot x$ \\
$x \cdot x \cdot x \cdot y$ \\
$x$
\end{tabular}

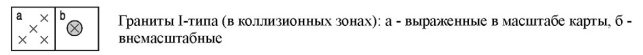

++++
+++

$a_{+}+{ }_{+}^{+}$
+

Синтектонические (синметаморфические) гнейсовидные гранитоиды зон смятия

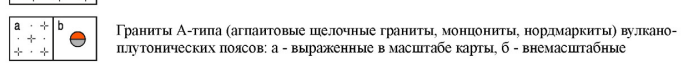

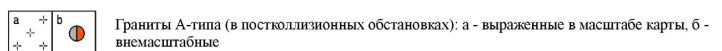

a

$++_{+}^{+}+\oplus \begin{aligned} & \text { онгониты) постколлизионных и рифтогснных обстановок: а - выражснныс в масштабо } \\ & \text { карты, } 6 \text { - внемасштабныс }\end{aligned}$

Граниты рапакиви (высокожслсзистыс высококалсвыс рифтогенныс)

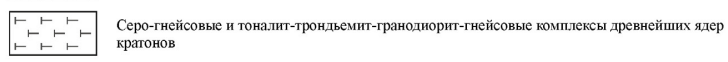

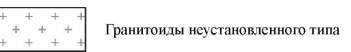

Хаотические и тектоногенные комплексы

Олистостромы н хаотнеские комплексы, не расчлененные по составу

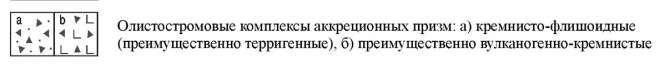

Милониты, бластомилониты зон смятия

Рис. 11. Литологический блок к Тектонической карте Северной, Центральной и Восточной Азии и сопредельных территорий масштаба 1:2500000 (см. рис. 8).

Fig. 11. Lithological data for the Tectonic Map of North, Central and East Asia and Adjacent Areas, scale 1:2500000 (see Fig. 8). 
океанической. Они широко проявились на рассматриваемой территории не только в пределах древних кратонов (Сибирского, Северо- и Южно-Китайского, Восточно-Европейского и Таримского), но и в зонах глыбовой тектоники и тектономагматической активизации в пределах складчатых поясов на постконсолидационных этапах их развития.

\section{4. ТЕКТОНИЧЕСКАЯ КАРТА АРКТИКИ МАСШТАБА 1:5000000}

Дальнейшее развитие охарактеризованный подход к тектоническому картографированию получил при составлении Тектонической карты Арктики масштаба 1:5000000 (TeMAr). Работы по ее созданию проводились в 2010-2018 гг. геологическими службами Норвегии, Канады, России, США, Дании, Швеции, Германии и Франции под эгидой Комиссии по Геологической карте мира при ЮНЕСКО (CGMW) при координации со стороны ВСЕГЕИ и завершились изданием карты в масштабе 1:10000000 в начале 2019 г. [Petrov, Pubelye, 2019] (рис. 12).

Карта охватывает северные районы континентальной части России (к северу от $60^{\circ}$ с.ш.) и прилегающие акватории Северного Ледовитого океана с окраинными морями, содержит целый ряд новых решений в части картографирования областей перехода типа континент - океан и океанических сегментов. Она обеспечивает увязку и целостность представления тектоники глубоководных океанических бассейнов, шельфов окраинных морей и континентального обрамления. В качестве самостоятельной группы картографируемых объектов на карте выделяются осадочные бассейны, которые занимают 70 \% всей площади Циркумполярной области.

Для этой карты была использована легенда Тектонической карты Северной, Центральной и Восточной Азии масштаба 1:2500000, адаптированная к масштабу и особенностям тектонического строения Арктического региона. Также были внесены изменения и дополнения с целью повышения информативности и наглядности карты. Значительно упрощен блок, отражающий вещественные комплексы (крап). С учетом исключительно важной роли рифтогенеза и мантийного магматизма в преобразовании континентальной коры и формировании металлогенического профиля территорий в легенде к Тектонической карте Арктики предусмотрен самостоятельный блок, отражающий процессы внутриплитной тектоники.

Легенда разделена на две основные группы по их принадлежности к доменам с континентальной или океанической земной корой.

К областям распространения континентальной коры относятся четыре раздела легенды: (1) кратоны и подвижные (орогенные или складчатые) пояса, (2) крупные магматические провинции и рифтовые системы, (3) осадочный чехол Арктики, представленный эпиконтинентальными осадочными бассейнами, платформенными чехлами и пассивными окраинами континентов, (4) разломы, складчатость и другие структурные элементы.

Кратоны и подвижные пояса характеризуются развитием двух групп породных ассоциаций, различающихся тектоническими режимами (сжатия или растяжения) и соответствующими им тектоническими обстановками.

Первая группа комплексов-индикаторов режима сжатия и утолщения земной коры связана с процессами формирования (аккреции) континентальной земной коры и включает вулканические, плутонические, осадочные и метаморфические комплексы различных эпох и фаз тектогенеза (складчатости, орогенеза, кратонизации), которые отражаются на карте цветом, соответствующим временному интервалу проявления субдукционных и коллизионных процессов, структурных деформаций, метаморфизма, гранитоидного магматизма, образования аккреционных призм, турбидитов, морских и континентальных моласс (рис. 13). Эти процессы не являются изохронными на обширных территориях, и поэтому возрастная шкала содержит конкретные примеры орогенических событий в разных регионах с указанием временных интервалов их проявления в миллионах лет.

Среди вулканических образований выделяются породные ассоциации островных дуг, активных континентальных окраин андийского типа, океанических и задуговых бассейнов. Осадочные ассоциации представлены аккреционными комплексами микститов и молассами. Вулканические и осадочные ассоциации показаны черным крапом. Исключение составляют обширные наложенные вулканические пояса типа Охотско-Чукотского, показанные для наглядности цветным крапом на светло-сером фоне.

К этой же группе комплексов-индикаторов отнесены метаморфические комплексы с преобладанием одной из фаций (зеленосланцевой, амфиболитовой, гранулитовой), а также архейские серогнейсовые (TTG) комплексы и породы палеопротерозойских гранулитгнейсовых поясов повышенного давления. Все метаморфические образования выделяются красным, высокобарические голубосланцевые и эклогитовые комплексы - синим крапом.

Из плутонических образований в эту группу комплексов включены аккреционные гранитоиды (М- и I-типы), коллизионные гранитоиды (S- и I-типы), а также зональные ультрамафит-мафитовые интрузивы платиноносных поясов уральско-корякского типа. Для плутонических пород предусмотрен крап белого цвета на цветном фоне.

Цвет для отражения возраста всех породных ассоциаций этой группы комплексов-индикаторов выбирается в соответствии с цветовой шкалой (рис. 13). Исключение составляют палеопротерозойские и более молодые гранитоиды, а также офиолиты и ультрамафит-мафитовые интрузивы. Палеопротерозойские и более молодые гранитоиды показаны двумя оттенками красного цвета. Малиновый оттенок принят для 
субдукционных M-І-типов, ярко-красный - для коллизионных S-I-типов гранитов. Архейские гранитоиды, условно по составу отнесенные к аккреционным или коллизионным (показано белым цветом), выделены цветами и индексами архея в соответствии со шкалой последовательности тектонических событий (рис. 13).

Палеоокеанические комплексы, представленные офиолитовыми аллохтонами, выделяются фиолетовым цветом и подразделяются на офиолитовый меланж, тектонические блоки с сохранившейся офиолитовой последовательностью комплексов-индикаторов палеоокеанической коры и офиолитовые сутуры. Протяженные узкие тектонические зоны с офиолитовым меланжем показаны знаком офиолитовых сутур с обозначением их возраста (в кружках).

Легенда дает возможность показать структурнотермальную переработку ранее сформированной земной коры и общую последовательность событий в тектонической эволюции аккреционно-коллизионных структур.

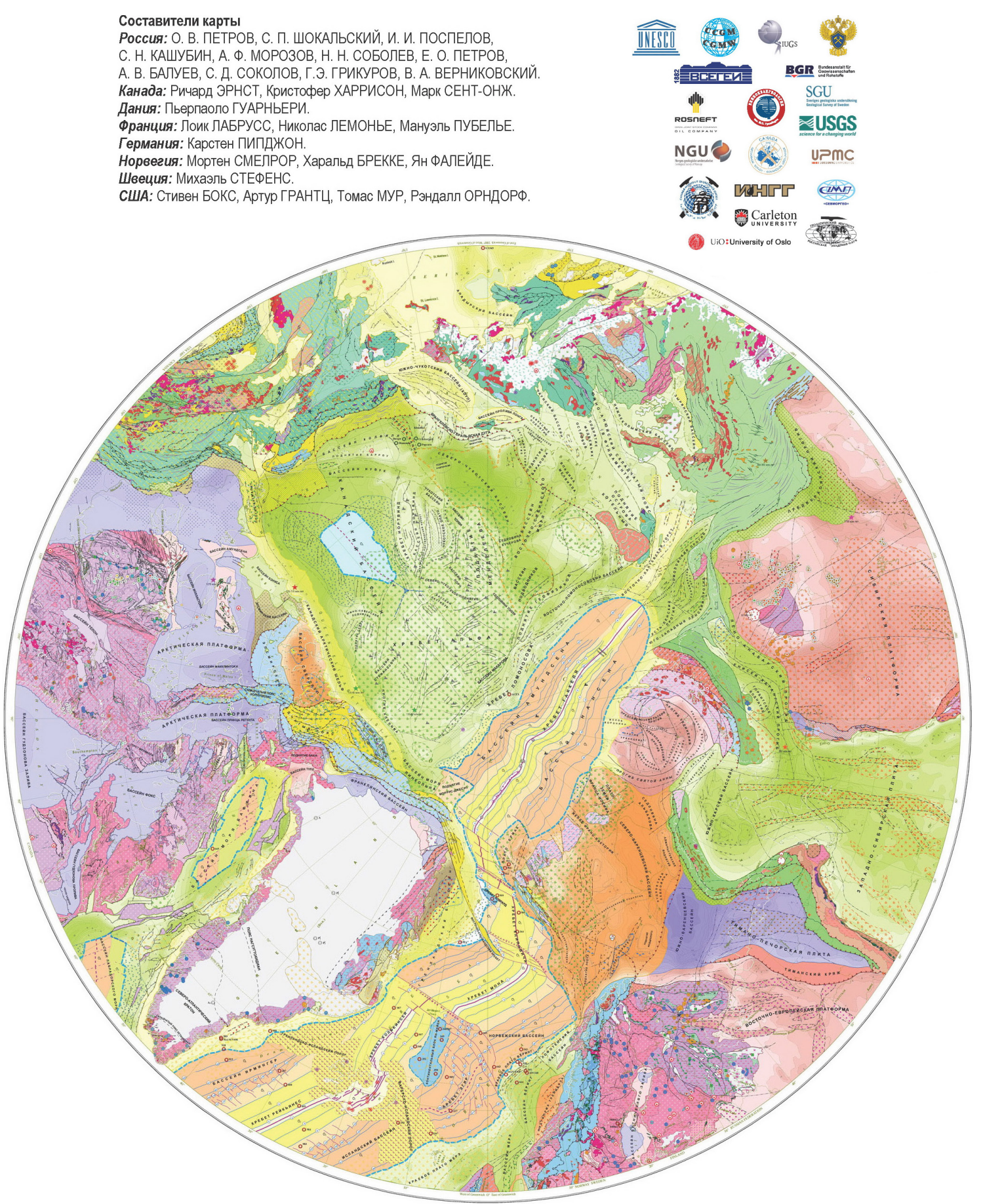

Рис. 12. Тектоническая карта Арктики масштаба 1:10000000, гл. редакторы О.В. Петров, М. Пубелье, 2019 г.

Fig. 12. Tectonic Map of the Arctic, scale 1:10000000. Chief Editors O.V. Petrov and M. Pubelier, 2019. 


\section{КОНТИНЕНТАЛЬНЫЕ ОБЛАСТИ}

\section{Кратоны и подвижные пояса}

\begin{tabular}{|c|c|c|c|c|c|c|}
\hline \multicolumn{2}{|c|}{$\begin{array}{c}\text { Эпохи } \\
\text { орогенеза }\end{array}$} & \multicolumn{5}{|c|}{ Фазы орогенеза } \\
\hline \multirow{3}{*}{ 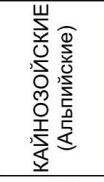 } & \multirow{3}{*}{ C } & \multicolumn{2}{|c|}{$\mathrm{C}_{3}$} & Валахская & \multirow{2}{*}{\multicolumn{2}{|c|}{$\begin{array}{l}\text { Тектонические события, не имеющие собственных } \\
\text { названий в Арктике (<40 млн лет) }\end{array}$}} \\
\hline & & \multicolumn{2}{|c|}{$\mathrm{C}_{2}$} & Штирийская & & \\
\hline & & \multicolumn{2}{|c|}{$\mathrm{C}_{1}$} & \multicolumn{3}{|c|}{$\begin{array}{l}\text { Эвриканская (61-45 млн лет), позднеларамийская (50-40 млн лет), } \\
\text { камчатская ( } 50-40 \text { млн лет) }\end{array}$} \\
\hline \multirow{3}{*}{ 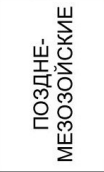 } & \multirow{3}{*}{ LM } & \multicolumn{2}{|c|}{$\mathrm{LM}_{3}$} & \multicolumn{3}{|c|}{ Раннеларамийская (80-50 млн лет) } \\
\hline & & \multicolumn{2}{|c|}{$\mathrm{LM}_{2}$} & \multicolumn{3}{|c|}{ Охотско-Чукотская (105-80 млн лет) } \\
\hline & & \multicolumn{2}{|c|}{$\mathrm{LM}_{1}$} & \multicolumn{3}{|c|}{ Чукотская (135-105 млн лет), брукская (125-110 млн лет) } \\
\hline \multirow{3}{*}{ 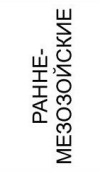 } & \multirow{3}{*}{ EM } & \multicolumn{2}{|c|}{$\mathrm{EM}_{3}$} & \multicolumn{3}{|c|}{$\begin{array}{l}\text { Позднекиммерийская (150-140 млн лет), верхоянская } \\
\text { (150-135 млн лет), невадийская (150-140 млн лет) }\end{array}$} \\
\hline & & \multicolumn{2}{|c|}{$\mathrm{EM}_{2}$} & \multicolumn{3}{|c|}{ Среднекиммерийская? (200-150 млн лет) } \\
\hline & & \multicolumn{2}{|c|}{$\mathrm{EM}_{1}$} & \multicolumn{3}{|c|}{ Раннекиммерийская (235-190 млн лет) } \\
\hline \multirow{3}{*}{ 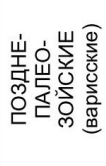 } & \multirow{3}{*}{ LP } & \multicolumn{2}{|c|}{$\mathrm{LP}_{3}$} & \multicolumn{3}{|c|}{ Уральская (300-250 млн лет), палатинская (260-250 млн лет) } \\
\hline & & & & Поздневарис & ская (310-275 млн лет) & \\
\hline & & & & Ранневарисо & кая (340-310 млн лет) & \\
\hline & & & & Элсмирская & (375-340 млн лет) & \\
\hline '哭 包 & & & & Свальбардске & я (380-330 млн лет), каледонская (440-410 млю & лет) \\
\hline 崖总 & EP & & & Таконская (4 & 30-430 млн лет) & \\
\hline 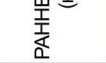 & & & & $\begin{array}{l}\text { Финмаркская } \\
\text { млн лет) }\end{array}$ & (510-480 млн лет), раннекаледонская (510- & -470 \\
\hline 仓่ & & & $\mathrm{P}_{3}^{3}$ & $\begin{array}{l}\text { Тиманская (6 } \\
\text { млн лет), ава }\end{array}$ & $\begin{array}{l}\text { 30-540 млн лет), позднебайкальская (600-540 } \\
\text { ллонская (570 млн лет) }\end{array}$ & $\stackrel{0}{\frac{1}{2}}$ \\
\hline $\begin{array}{l}5 \\
0, \frac{8}{0} \\
0\end{array}$ & & $P_{3}$ & $P_{3}^{2}$ & Среднебайкє & льская (800-600 млн лет) & 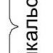 \\
\hline 峁 & & & $P_{3}^{1}$ & Раннебайкал & ьская (870-800 млн лет) & மึ \\
\hline 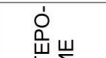 & & & $P_{2}^{3}$ & $\begin{array}{l}\text { Гренвильск } \\
\text { (1,2-0,9 млр }\end{array}$ & $\begin{array}{l}\text { я }(1,14-0,88 \text { млрд лет), свеконорвежска } \\
\text { лет), дальсландская }(1,1-0,9 \text { млрд лет) }\end{array}$ & \\
\hline 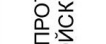 & $P$ & $\mathrm{P}_{2}$ & $\mathrm{P}_{2}^{2}$ & Эльсонская & 1,4-1,25 млрд лет) & \\
\hline 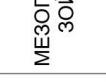 & & & $P_{2}^{1}$ & $\begin{array}{l}\text { Халландскаء } \\
\text { млрд лет), дағ } \\
\text { млрд лет) }\end{array}$ & $\begin{array}{l}\text { (1,47-1,42 млрд лет), телемаркская (1,52- } \\
\text { опольская (1,5-1,4 млрд лет), иотнийская (1,64 }\end{array}$ & $\begin{array}{l}1,48 \\
-1,42\end{array}$ \\
\hline щ & & & $P_{1}^{3}$ & Даларнийска & я (1,72-1,52 млрд лет) & \\
\hline 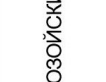 & & $P_{1}$ & $P_{1}^{2}$ & $\begin{array}{l}\text { Свекофенска } \\
\text { вопмейская (1 } \\
\text { лапландская }\end{array}$ & $\begin{array}{l}\text { (2,1-1,75 млрд лет), телонская (1,99-1,91 млрд } \\
89-1,84 \text { млрд лет), гудзонская (1,85-1,79 млрд } \\
\text { (1,94-1,85 млрд лет) }\end{array}$ & лет), \\
\hline 㞻 & & & $P_{1}^{1}$ & Раннекарель & ская (2,5-2,3 млрд лет) & \\
\hline 등 & & & & Беломорская & (2,7-2,6 млрд лет), кеноранская (2,72-2,65 млрд & лет) \\
\hline$\frac{5}{c}$ & & & & Кольская $(3,2$ & $-2,8$ млрд лет) & \\
\hline , & H & & & Белозерская & (3,5-3,2 млрд лет) & \\
\hline 宸 & & & & $\begin{array}{l}\text { Формирован } \\
\text { Исуа }-3,7 \text { мл }\end{array}$ & $\begin{array}{l}\text { е древнейшей континентальной коры (компл } \\
\text { iрд лет, Амитсок - 3,9-3,6 млрд лет, Акаста. }\end{array}$ & \\
\hline
\end{tabular}

Структурно-термальная переработка тектонических единиц

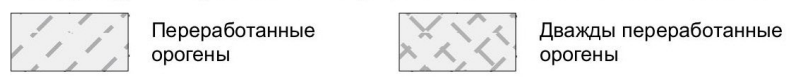

Примечание. Цвет итриховки на карте отражает время переработки ранее образованных тектонических комплексов

\section{Аккреционно-коллизионные породные ассоциации}

\section{Вулканические ассоциации}

Базальты и плагиориолиты энсиматических островных дуг

Андезиты, дациты, риолиты энсиалических островных дуг и активных континентальных окраин ${ }^{2}$

Базальты задуговых бассейнов

Нерасчлененные вулканические образования

\section{Осадочные отложения}

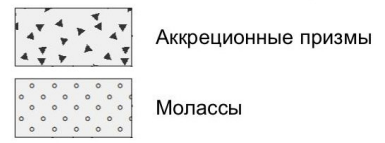

\section{Метаморфические образования ${ }^{1}$}

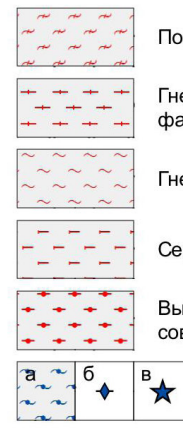

Породы зеленосланцевой фации метаморфизма

нейсы, амфиболиты и мигматиты (в основном амфиболитовая фация метаморфизма)

Гнейсы и амфиболиты (преимущественно гранулитовая фация) Серогнейсовые (тоналит-трондьемит-гранодиоритовые) ассоциации

Высокобарические метаморфические комплексы гранулит-гнейСовых поясов

Метаморфические комплексы высоких давлений: a - голу-
босланцевые, б - внемасштабные проявления голубых сланбосланцевые, б - внемасштабные проявления гол
цев, в - внемасштабные проявления эклогитов

цев, в - внемасштабные проявления эклой

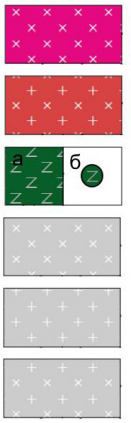

Надсубдукционные гранитоиды (М- и І-типы) ${ }^{4}$

Коллизионные гранитоиды (S- и I-типы) ${ }^{4}$

Зональные ультрамафит-мафиитовые массивы уральско-аляскинского типа с сульфиидно-платиноидной минерализацией (а - выражающиеся в масштабе карты, б - малые внемасштабные тела)

Архейские, предположительно надсубдукционные, гранитоиды М- и І-типов

Архейские коллизионные гранитоиды S- и I-типов

Архейские нерасчлененные плутонические ассоциации ${ }^{1}$

\section{Комплексы палеоокеанической коры}

Офиолитовые аллохтоны (а - выражающиеся в масштабе карты, б-малые внемасштабные тела)

Полнопроявленные с сохранившейся последовательностью офиолитовые комплексы палеоокеанической коры

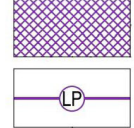

Офриолитовые сутуры и их возраст

Примечания: 1 - цвет полигона отражает время тектонического события (берется из цветовой шкалы "эпохи и фозы орогенеза"); 2 - недеформированные наложенные вулканические пояса показываются цветным крапом на белом фоне (для Охотско-Чукотского и кайнозойских вулканических поясов СевероВостока России); 3 - нерасчлененные осадочные образования даны на карте без крапа; 4 - цвет полигона отражает тектонический тип гранитов, ивет крапа - возраст пород

Рис. 13. Легенда к Тектонической карте Арктики масштаба 1:5000 000. Области с континентальной корой. Кратоны и подвижные пояса.

Fig. 13. Legend of the Tectonic Map of the Arctic, scale 1:5000000. Continental crust. Cratons and fold belts. 
Вторая группа комплексов-индикаторов крупных магматических провинций и рифтовых систем объединяет магматические комплексы, которые определяют режим растяжения и утонения земной коры, внутриплитные анорогенные тектонические обстановки. С целью контрастного отображения на карте этих комплексов, маркирующих деструкцию ранее сформированной континентальной коры, для отражения их возраста используется отдельная временная шкала (рис. 14), в которой разным цветом выделяются девять этапов проявления внутриплитного магматизма и рифтинга от архея (M1) до кайнозоя (М9). Для каждого этапа приведены примеры крупных магматических провинций, дайковых поясов и рифтов по Гренландии, Канаде, Аляске, Восточной России и Северной Европе. При этом жирным шрифтом выделены наиболее известные и типичные магматические комплексы. Большая их часть приводится по данным Международной комиссии по крупным магматическим провинциям (LIPs), возглавляемой Р. Эрнстом [Ernst, 2014].

Зеленокаменные пояса рассматриваются как архейские проторифтовые структуры (событие M1), в пределах которых точечными знаками показаны проявления коматиитов. Возраст более молодых рифтов отражается с помощью цветного точечного крапа (цветовая шкала М2-М9) внутри черного контура рифта. Цветными линиями показываются границы вулканических ареалов и полей; цветным крапом (по шкале M2-M9) на светло-сером фоне - поля распространения платобазальтов, бимодальных вулканических серий и габбро-долеритов.

Внутриплитные плутоны показаны разным цветом по составу пород: ультрамафит-мафитовые расслоенные массивы - синим цветом, габбро и дайки долеритов - зеленым, рапакиви - розовым, щелочные интрузивы - оранжевым. При этом мелкие (внемасштабные) интрузивные тела показаны точечными знаками соответствующего цвета. Цветными точечными знаками на карте выделяются кимберлитовые трубки, проявления лампроитов и карбонатитов, эпицентры плюмовой активности.

Осадочный чехол объединяет недеформированные и слабодеформированные осадочные структуры (на континентальной коре) с мощностью осадков более 1 км, включая эпиконтинентальные осадочные бассейны, платформенные чехлы и пассивные арктические окраины континентов (рис. 15). В зависимости от времени начала главного погружения бассейны подразделяются на семь поколений (B1-B7). Каждому из них присуща своя цветовая гамма. Интенсивность цвета при закраске бассейна определяется мощностью осадочного чехла. Наиболее древние бассейны В1 характеризуются началом формирования осадочного чехла со второй половины палеопротерозоя (2050-1600 млн лет); их реликты сохранились в пределах Канадского щита. Самые молодые бассейны В7 начали свое формирование в палеогене - неогене, в обстановке континентального рифтинга или транстенсии вдоль крупных сдвигов, как грабены. Они приурочены к шельфовым окраинам Канадского арктического архипелага, Лаптевоморскому и Восточносибирскому шельфам. Границы бассейнов обозначаются цветными линиями в соответствии с их возрастом. Специальной линией показываются границы погребенных бассейнов. Мощность осадочного чехла отражается изопахитами. В случае наложения разновозрастных бассейнов показывается суммарная мощность осадков.

Цветной сеточкой отображаются участки осадочных бассейнов, испытавшие «холодную» (структурную) переработку чехла (пологую складчатость). В Арктике она наиболее отчетливо проявилась в среднем палеопротерозое, в поздней юре - раннем мелу, в раннем - позднем мелу и кайнозое, особенно в осадочных бассейнах, прилегающих к складчатым поясам.

В структуре осадочного чехла Циркумполярной Арктики наблюдается периферический пояс глубоких шельфовых бассейнов (Южно-Баренцевский, Южнои Северо-Карские, Северо-Чукотский, моря Бофорта, продельты Маккензи, Свердруп, моря Линкольна и др.). Мощность осадочного чехла в них достигает 14-18 км; при этом до половины общей мощности осадочного разреза образуют палеозойско-раннемезозойские отложения, выше которых залегают мощные (до 8-10 км) позднемезозойско-кайнозойские толщи. Такие прогибы образуются в результате последовательного проявления двух или более эпизодов континентального рифтинга и осадконакопления, например рифтогенного пермско-триасового и предгорного позднемезозойского в Северо-Чукотском бассейне и Прогибе Ханна.

Прочие структурные элементы в областях с континентальной корой представлены разрывными нарушениями различных кинематических типов: сбросами и листрическими сбросами, сдвигами, взбросами и надвигами (рис. 16). Линейными условными знаками показаны структурные фронты деформаций и геологические границы. На карте показаны зоны линейной складчатости, соляная тектоника, современные вулканы, опорные параметрические скважины на шельфе и скважины, вскрывшие подледный фундамент в центральной части Гренландского щита.

Области с океанической корой имеют цветовую закраску, отражающую возраст новообразованной океанической коры в соответствии со шкалой, рекомендованной CGMW и реализованной на новейших структурных картах Атлантического и Индийского океанов (рис. 17). Легенда TеMAr содержит цветные обозначения для наиболее распространенной маломощной (5-7 км) океанической коры, сформировавшейся в результате спрединга: в поздней юре(?) - раннем мелу в центральной части Канадского бассейна, в палеоцене в заливе Баффина и Лабрадорском море, в позднем палеоцене - голоцене в Северной Атлантике и Евразийском океаническом бассейне (01-06). Для отображения коры на карте использован тектоно-стратиграфический атлас Северо-Восточной Атлантики, изданный 


\section{КРУПНЫЕ МАГМАТИЧЕСКИЕ ПРОВИНЦИИ, СИЛЛОВО-ДАЙКОВЫЕ ПОЯСА И РИФТОВЫЕ СИСТЕМЫ}

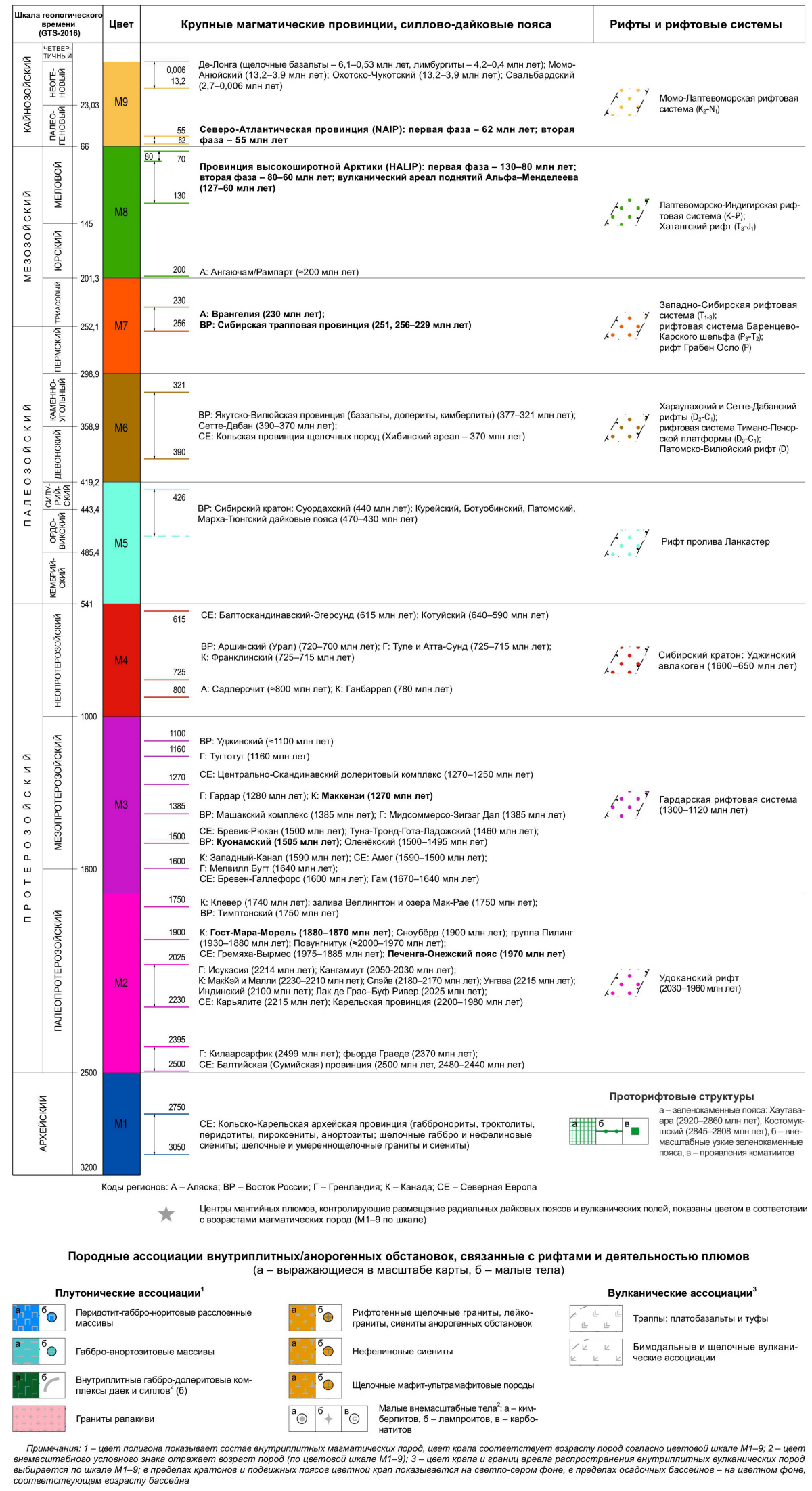

Рис. 14. Легенда к Тектонической карте Арктики масштаба 1:5000000. Области с континентальной корой. Крупные магматические провинции, силлово-дайковые пояса, рифтовые системы.

Fig. 14. Legend of the Tectonic Map of the Arctic, scale 1:5000000. Continental crust. Large igneous provinces, sill-dyke belts, and rift systems. 


\section{Осадочный чехол}

(эпиконтинентальные бассейны, платформенные чехлы, пассивные окраины)

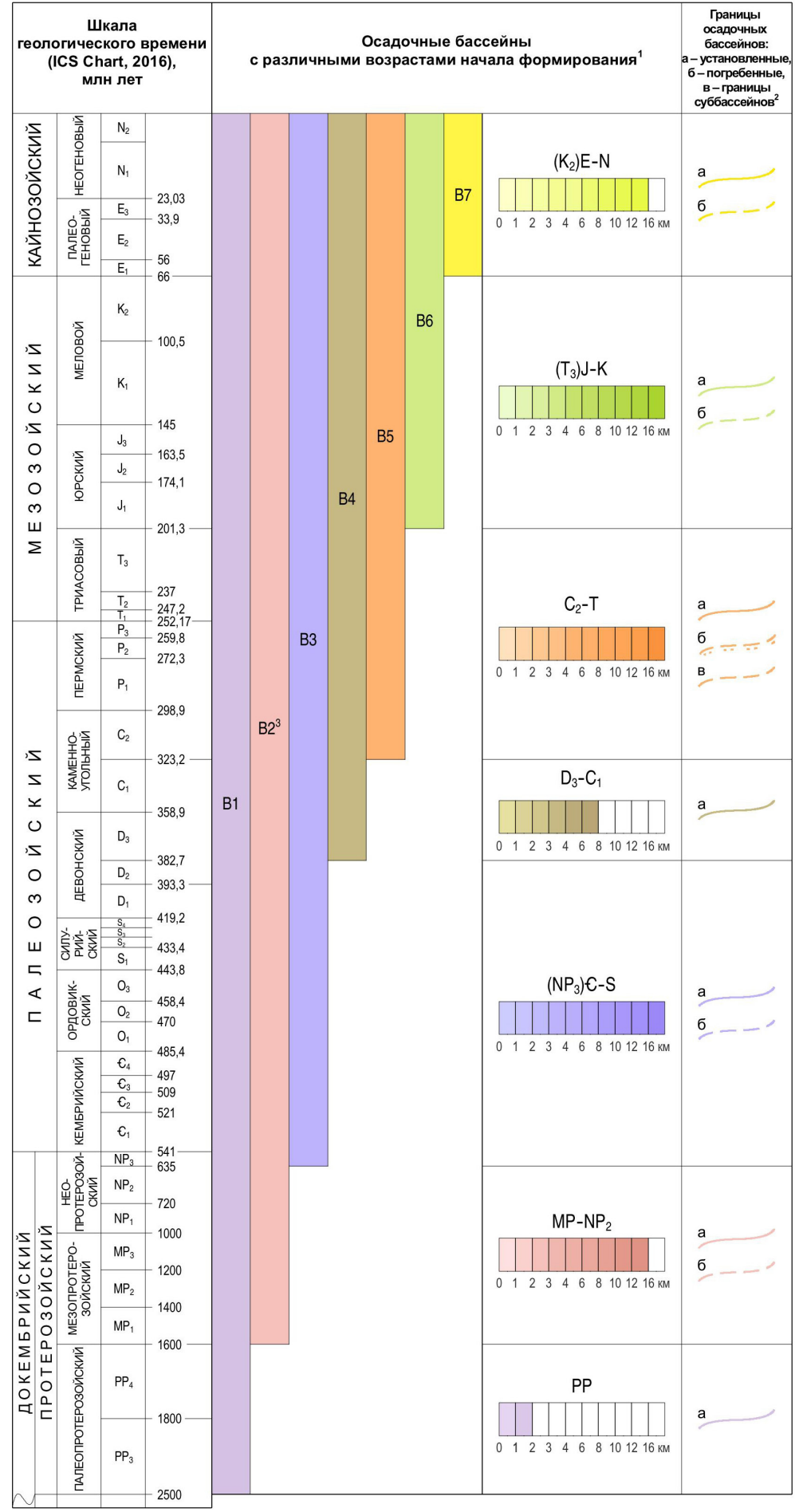

Примечания: 1 - ивет показывает время начала главного этапа погружения бассейна; 2 - условная граница между смежными сосуществующими осадочными бассейнами (суббассейнами); 3 - пост-палеопротерозойские бассейны - B2.1,

....12..... Изопахиты, км

Зоны складчатых деформаций в осадочных чехлах

Осадочные чехлы, деформированные:
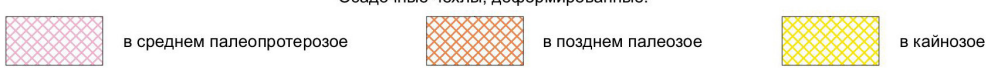

Рис. 15. Легенда к Тектонической карте Арктики масштаба 1:5000000. Области с континентальной корой. Осадочный чехол. Fig. 15. Legend of the Tectonic Map of the Arctic, scale 1:5000000. Continental crust. Sedimentary cover. 


\section{СТРУКТУРНЫЕ ЭЛЕМЕНТЫ}

\section{Разломы и структурные фронты}

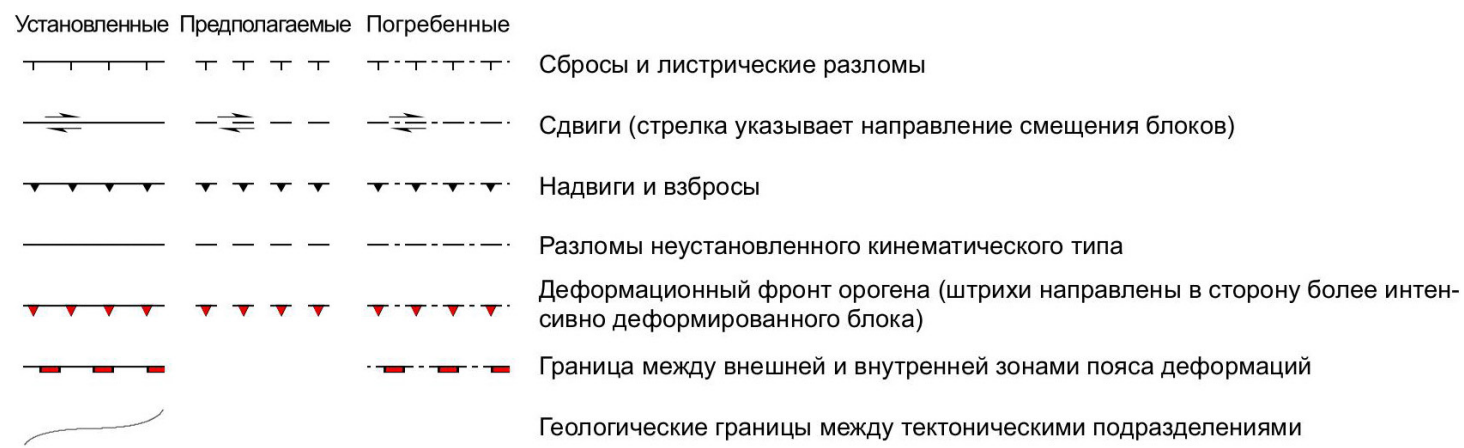

Прочие

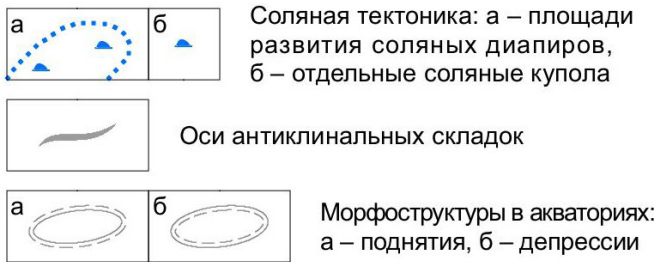

Импактные структуры: а - крупные, б - малые (внемасштабные) с указанием их возраста, млн лет

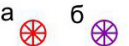
шие

Рис. 16. Легенда к Тектонической карте Арктики масштаба 1:5000000. Структурные элементы.

Fig. 16. Legend of the Tectonic Map of the Arctic, scale 1:5000000. Structural elements.

геологической службой Дании и Гренландии под ред. Джона Хоппера в 2014 г.

Особым условным знаком показаны структуры Исландско-Фарерского хребта с резко утолщенной мафической корой и внутриплитным платобазальтовым вулканизмом. При этом взаимодействуют очаги спредингового и внутриплитного магматизма. Для новообразованной океанической коры в Исландско-Фарерском поднятии присутствует океаническая кора плейстоцен-голоценового (менее 2.6 млн лет) и среднемиоцен-плиоценового (15.0-2.6 млн лет) возраста. Кроме того, по унаследованным детритовым цирконам и геофизическим данным в Исландском плато предполагается присутствие реликтов палеозойской континентальной коры.

В соответствии с легендой на карте показаны ключевые линейные магнитные аномалии (магнитные хроны 2, 5, 6, 13, 18, 20, 21, 24 и 25), большинство из которых служит маркерами при определении возраста спрединговой океанической коры.

Легенда содержит условные обозначения для переходной зоны континент - океан, в которой предполагается сонахождение эксгумированной мантии, фрагментов предельно растянутой континентальной коры и вулканических пород. Такие зоны предполагаются, по сейсмическим данным, в центральной части Канадской котловины и в амагматичном сегменте хребта Гаккеля с выходами перидотитов мантии на его гребне.

Легендой предусматриваются условные знаки для границы континент - океан, осей спрединга - активных и отмерших, трансформных разломов (активных и отмерших), линейных магнитных аномалий с номерами хронов, характерных для Евразийского океанического бассейна.

На Чукотском плато и хребте Ломоносова выявлены обширные поверхности выравнивания, по-видимому, сформировавшиеся в субаэральных условиях при активной эрозионной деятельности морской воды и ледников. На поднятии Менделеева-Альфа широко распространены горстовые выступы подводных гор и отчетливо проявлена блоковая структура с горст-грабеновыми системами, по-разному ориентированными в соседних блоках. В центральной части Канадской котловины показана трехлучевая разломная структура глубокого растяжения континентальной коры, выраженная гребневидными выступами мантии на карте Мохо. Два ее «луча» контролируют размещение обширного поля меловых внутриплитных вулканитов HALIP, а вдоль третьего, предположительно, проявилась зона мелового спрединга.

Таким образом, в отличие от Евразийского океанического бассейна, в глубоководном Амеразийском бассейне обнаружены и зафиксированы в легенде и на карте многочисленные признаки активной неотектоники, типичные для континентальной земной коры.

Тектоническая карта Арктики сопровождается набором дополнительных карт, которые отражают глубинное строение региона, тектоническое районирование фундамента и типы земной коры, а также глубинным геотрансектом и объяснительной запиской.

Как отмечалось выше, осадочный чехол в Арктике, показанный на базовой Тектонической карте, занимает 


\section{ОКЕАНИЧЕСКИЕ ОБЛАСТИ}

\section{Океаническая кора}

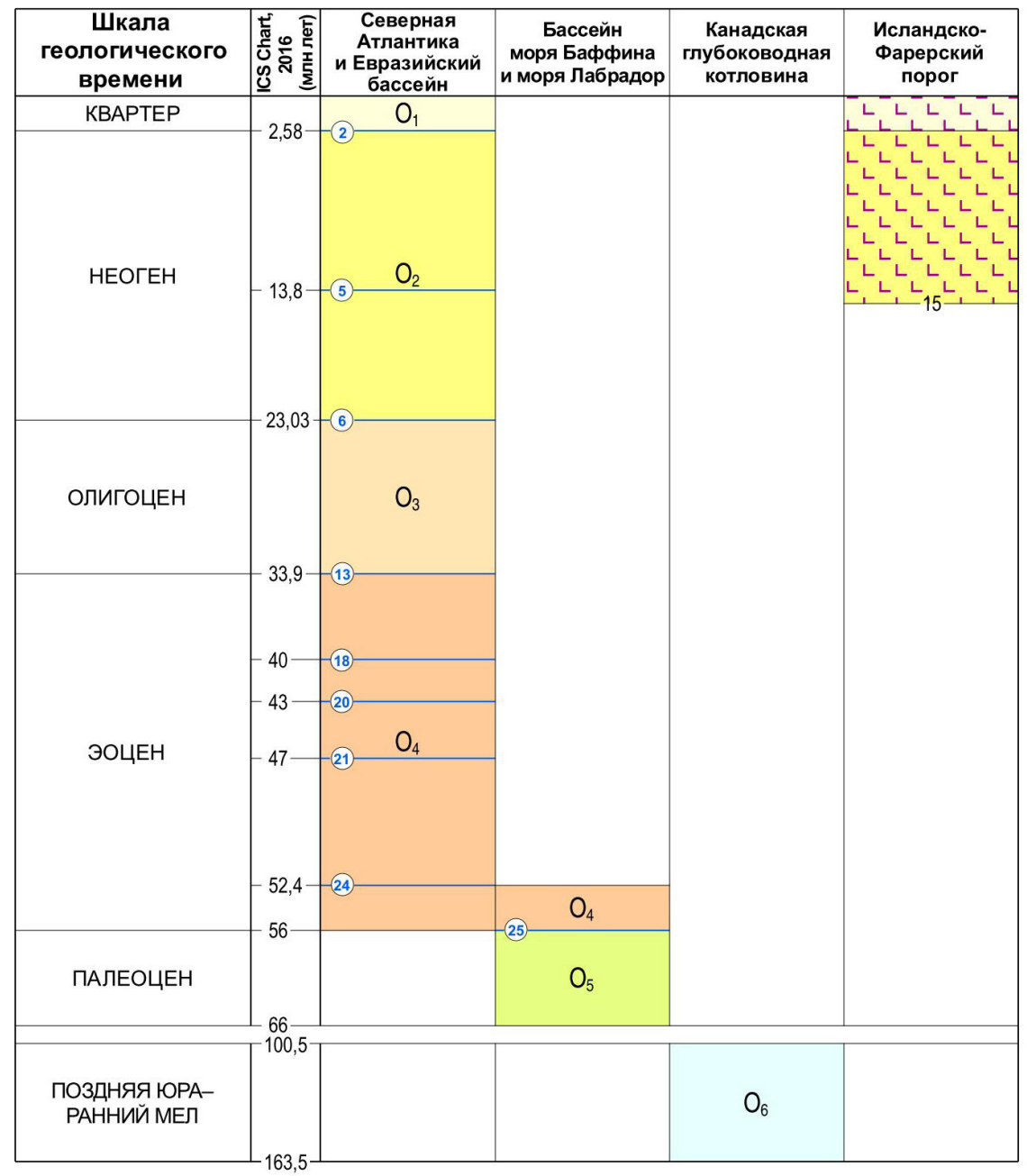

а Выходящие на поверхность морского дна серпентинизированные перидотиты верхней мантии в хребте Гаккеля - сегменте с угнетенным магматизмом (a), отдельные участки (б)

Переходная зона континент-океан (крайне растянутая и утонченная континентальная кора, локально проявленные вулканиты, серпентинизированные перидотиты верхней мантии)

Поверхности выравнивания на хребте Ломоносова и Чукотском плато

\section{Структурные элементы в областях распространения океанической коры}

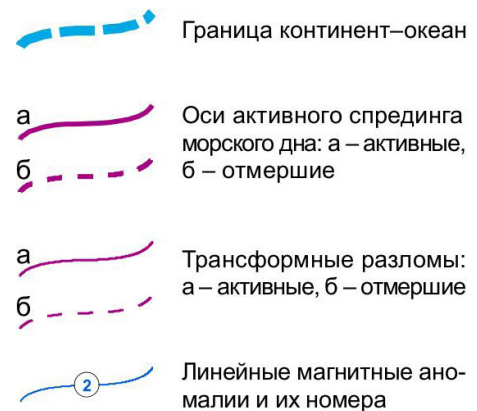

Сочпенение сквозькоровых разломов в пределах утоненной континентальной коры и переходной зоны континент-океан в Канадской котловине

М Подводные горы

Скважины глубоководного океанического бурения (программы DSDP, ODP, IODP)

Параметрические скважины морского буре-

(-) ния на шельфе Аляски: Popcom, Crackerjack, Klondike, Burger, Diamond

Глубокие скважины, достигшие фундамента во внутриматериковом ледовом покрове Гренландии

Рис. 17. Легенда к Тектонической карте Арктики масштаба 1:5000000. Области с океанической корой.

Fig. 17. Legend of the Tectonic Map of the Arctic, scale 1:5000000. Oceanic crust. 
до 70 \% площади Циркумполярной области. Для отражения представлений авторов о подстилающей для осадков консолидированной коры, ее типе и возрасте в комплект TeMAr включена дополнительная схема тектонического районирования фундамента Арктики.

На ней чехол снят и, наряду со щитами и складчатыми поясами и в соответствии с имеющимися геолого-геофизическими данными, показаны погребенные структуры с их продолжением под осадками шельфа в прилегающие глубоководные области Арктического бассейна (рис. 18). В основу схемы положены данные по тектонике прибрежной суши и шельфовых островных поднятий и профили ГСЗ, пересекающие область
Центрально-Арктических поднятий; она учитывает результаты интерпретации потенциальных полей, состав и возраст пород из обнажений на морском дне.

На схеме показаны границы распространения континентальной и океанической земной коры различного возраста, а также переходной зоны между ними, выделяемой по сейсмическим данным. Возраст геологических структур фундамента определяется временем консолидации континентальной земной коры и ее последующей структурно-термальной переработки.

Легенда к схеме (рис. 19) содержит условные обозначения, позволяющие показать: (1) в областях с континентальной корой - архей-палеопротерозойские

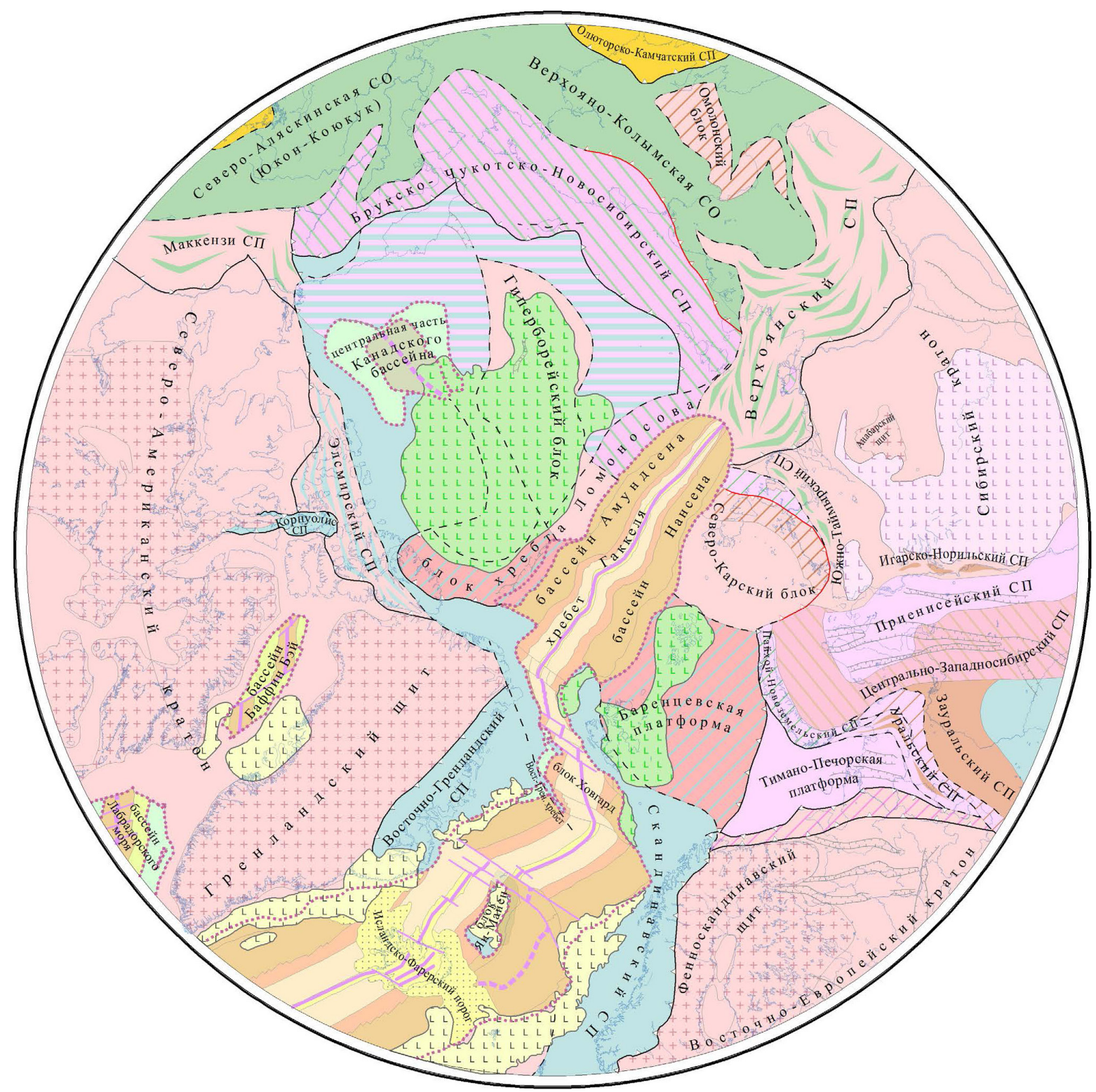

Рис. 18. Схема тектонического районирования фундамента Арктики (составлена с использованием публикаций [Grantz et al., 2009; Harrison et al., 2011; Morozov et al., 2013; Pease et al., 2014; Petrov et al., 2016a; Poselov et al., 2014; Proskurnin et al., 2012; Vernikovsky et al., 2013; и др.] и фондовых источников).

Fig. 18. Tectonic zoning of the Arctic basement (using data from [Grantz et al., 2009; Harrison et al., 2011; Morozov et al., 2013; Pease et al., 2014; Petrov et al., 2016a; Poselov et al., 2014; Proskurnin et al., 2012; Vernikovsky et al., 2013], other publications and archive sources). 


\section{УС Л О В Н Е О БО ЗН АЧ ЕНИЯ}

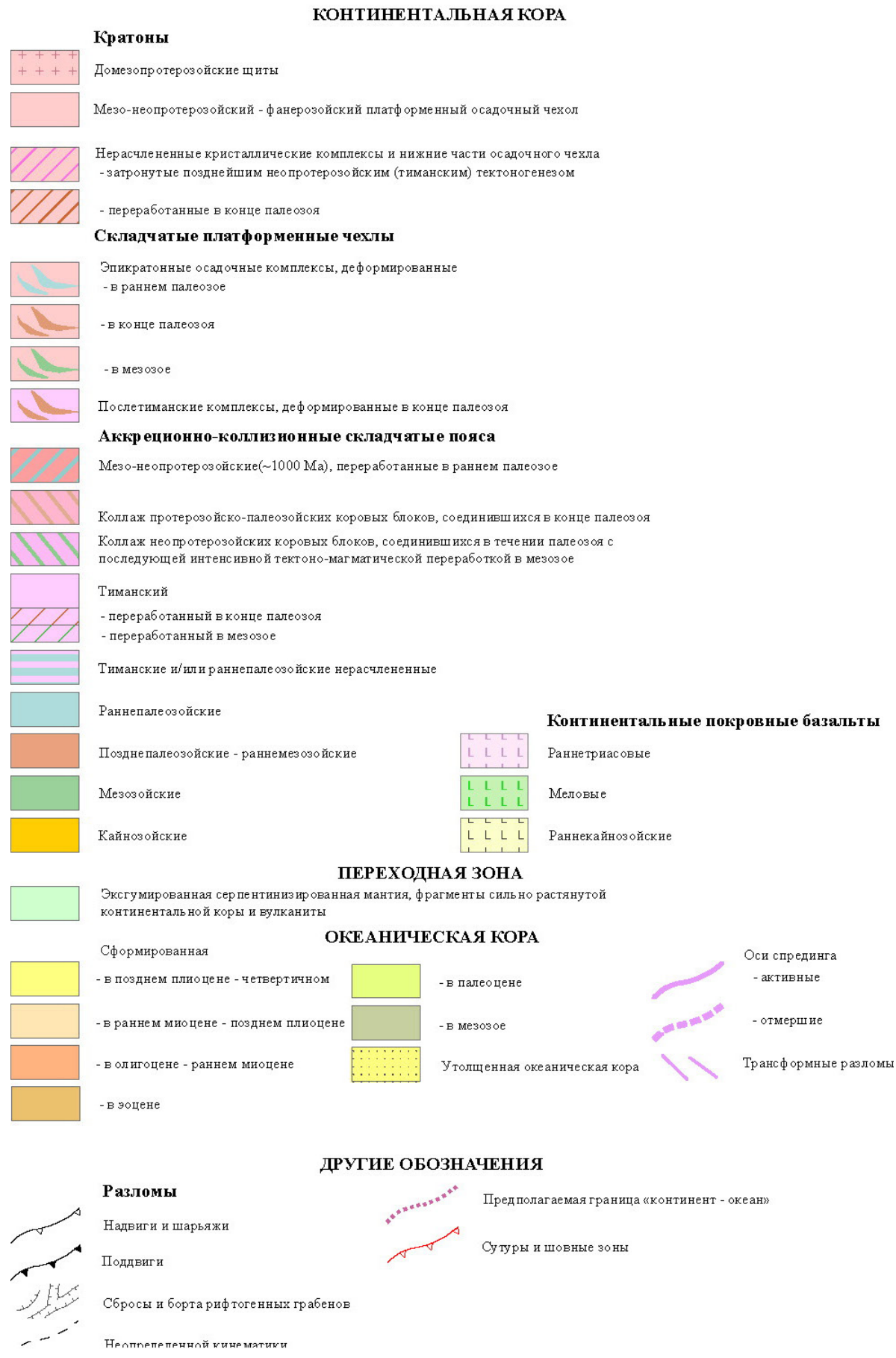

Рис. 19. Условные обозначения к схеме тектонического районирования фундамента Арктики (см. рис. 18).

Fig. 19. Legend of the schematic map showing tectonic zoning of the Arctic basement (see Fig. 18).

кратоны (с недеформированными или же переработанными в мезонеопротерозое и палеозое платформенными чехлами); разновозрастные складчатые пояса; обширные трапповые провинции триасового, мелового и палеогенового возраста; (2) в океанических доменах - распространение спрединговой океанической коры позднего мезозоя и кайнозоя (2-6 км) и утолщенной (до 20-30 км) океанической коры исландского типа.
На границе континентальной и океанической коры локально проявлена «переходная зона», представленная предельно утоненной континентальной корой.

Кроме того, на схеме показаны некоторые наиболее важные структурные элементы, такие как: граница «континент - океан», сутуры, разломы (сбросы и надвиги), крупные грабены, а также оси спрединга в срединно-океанических хребтах и зоны трансформных разломов. 
Схема тектонического районирования фундамента Циркумполярной области составлена с учетом новейших геологических и геохронологических данных по арктической островной и прибрежной суше. При ее составлении использован большой объем новой геологической информации, который был получен в последнее время в результате проведения региональных сейсмических работ на шельфе моря Лаптевых, Восточно-Сибирского и Чукотского морей, а также при геологическом изучении Новосибирских островов и острова Врангеля международными экспедициями в 2011, 2012, 2014 гг. [Petrov et al., 2016a]. В ходе создания схемы учитывались и данные, полученные геологами Дании, Норвегии, Канады и США в рамках национальных программ по научному обоснованию границ расширенного шельфа в Арктике. При этом на схеме на основе комплексных геолого-геофизических данных скоррелированы и взаимоувязаны основные структурные элементы суши и шельфа Северо-Восточной Арктики и глубоководные структуры области ЦентральноАрктических поднятий.

Объяснительная записка к Тектонической карте Арктики содержит пояснения к карте, характеристики принципов составления и содержания легенды, тектонического строения фундамента, описания тектонической модели и геодинамической эволюции Арктики.

\section{5. ЗАКЛЮЧЕНИЕ}

Составленные в последние годы усилием международных коллективов, при координации со стороны ВСЕГЕИ, Тектоническая карта Северной, Центральной и Восточной Азии и сопредельных территорий масштаба 1:2500000 и Тектоническая карта Арктики масштаба 1:5000000 получили высокую оценку Комиссии по геологической карте мира (CGMW). Положенные в их основу принципы являются естественным развитием традиционных подходов в отечественной тектонической картографии, изобразительные средства и зарамочное оформление соответствуют лучшим отечественным и зарубежным образцам. Опыт, полученный при их составлении, планируется к широкому применению в Международной тектонической карте Азии масштаба 1:5000000 (ITMA-5000) и Тектонической карте России масштаба 1:2500000, создание которых предполагается в ближайшее время.

\section{6. БЛАГОДАРНОСТИ}

Авторы благодарят сотрудников Института геологии и минералогии СО РАН А.Г. Владимирова и И.Ю. Анникову и ФГБУ «ВСЕГЕИ» Т.Ю. Толмачеву за помощь в подготовке публикации.

\section{7. ЛИТЕРАТУРА/REFERENCES}

Bogdanov A.A., Zonenshain L.P., Muratov M.V., Nalivkin V.D., Pushcharovsky Yu.M., Khain V.E., Zeisler V.M., Streis N.A., 1972. Tectonic Nomenclature and Classification of the Main Structural Elements of the Earth's Crust of Continents. Geotectonics 5, 3-21 (in Russian) [Богданов A.A.,
Зоненшайн Л.П., Муратов М.В., Наливкин В.Д., Пущаровский Ю.М., Хаин В.Е., Цейслер В.М., Штрейс Н.А. Тектоническая номенклатура и классификация основных структурных элементов земной коры материков // Геотектоника. 1972. № 5. С. 3-21].

Ernst R.E., 2014. Large Igneous Provinces. Cambridge University Press, London, 653 p. https://doi.org/10.1017/ CB09781139025300.

Grantz A., Scott R.A., Drachev S.S., Moore T.E., 2009. Maps Showing the Sedimentary Successions of the Arctic Region (58-64 to $90^{\circ}$ Degrees N) That May Be Prospective for Hydrocarbons. American Association of Petroleum Geologists, Tulsa, OK, USA, 86 p.

Harrison J.C., St-Onge M.R., Petrov O.V., Strelnikov S.I., Lopatin B.G., Wilson F.H., Tella S., Paul D., Lynds T., Shokalsky S.P., Hults C.K., Bergman S., Jepsen H.F., Solli A., 2011. Geological Map of the Arctic. Scale 1:5000000. Geological Survey of Canada, Ottawa, 9 sh. https://doi.org/10.4095/287868.

Khain V.E., Leonov Yu.G. (Eds), 1978. Tectonics of Europe and Related Areas. Explanatory Note to the International Tectonic Map of Europe and Adjacent Areas. Scale 1:2500000. Vol. 1. Nauka, Moscow, 422 p. (in Russian) [Тектоника Европы и смежных областей: Объяснительная записка к Международной тектонической карте Европы и смежных областей масштаба 1:2500000 / Ред. В.Е. Хаин, Ю.Г. Леонов. М.: Наука, 1978. Т. 1. 422 с.].

Khain V.E., Leonov Yu.G., Leonov M.G. (Eds), 1998. International Tectonic Map of Europe. Scale 1:5000000. VSEGEI Publishing House, Saint Petersburg, 6 sh. (in Russian) [Meждународная тектоническая карта Европы. Масштаб 1:5000000 / Ред. В.Е. Хаин, Ю.Г. Леонов, М.Г. Леонов. СПб.: Изд-во ВСЕГЕИ, 1998. 6 Л.].

Leonov M.G., Leonov Yu.G., 2002. On the Concept of «Consolidated Crust» and Its Boundaries. Lithosphere 4, 3-21 (in Russian) [Леонов М.Г., Леонов Ю.Г. О понятии «консолидированная кора» и ее границах // Литосфера. 2002. № 4. C. 3-21].

Leonov Yu.G., Khain V.E. (Eds), 1988. Tectonics of Continents and Oceans. Explanatory Note to the International Tectonic Map of the World. Scale 1:15000000. Nauka, Moscow, 245 p. (in Russian) [Тектоника континентов и океанов: Объяснительная записка к международной тектонической карте мира масштаба 1:15000000 / Ред. Ю.Г. Леонов, В.Е. Хаин. М.: Наука, 1988. 245 с.].

Morozov A.F., Petrov O.V., Shokalsky S.P., Kashubin S.N., Kremenetsky A.A., Shkatov M.Yu., Kaminsky V.D., Gusev E.A. et al., 2013. New Geological Evidence Confirming the Continental Nature of the Central Arctic Uplifts. Regional Geology and Metallogeny 53, 34-56 (in Russian) [Морозов А.Ф., Петров О.В., Шокальский С.П., Кашубин С.Н., Кременецкий А.А., Шкатов М.Ю., Каминский В.Д., Гусев Е.А. и др. Новые геологические данные, обосновывающие континентальную природу области Центрально-Арктических поднятий // Региональная геология и металлогения. 2013. № 53. С. 34-56].

Pease V.L., Kuzmichev A.V., Danukalova M.K., 2014. The New Siberian Islands and Evidence for the Continuation of the Uralides, Arctic Russia. Journal of the Geological 
Society 172 (1), 1-4. https://doi.org/10.1144/jgs20 14-064.

Peive A.V., 1969. Oceanic Crust of Geological Past. Geotectonics 4, 5-23 (in Russian) [Пейве А.В. Океаническая кора геологического прошлого // Геотектоника. 1969. № 4. C. 5-23].

Peive A.V., Shtreis N.A., Mossakovsky A.A., Perfiliev A.S., Ruzhentsev S.V., Bogdanov N.A., Burtman V.S., Knipper A.L. et al., 1972. Paleozoids of Eurasia and Some Issues of the Evolution of the Geosynclinal Process. Soviet Geology 12, 7-25 (in Russian) [Пейве А.В., Штрейс Н.А., Моссаковский А.А., Перфильев А.С., Руженцев С.В., Богданов Н.А., Буртман В.С., Книппер А.Л. и др. Палеозоиды Евразии и некоторые вопросы эволюции геосинклинального процесса // Советская геология. 1972. № 12. С. 7-25].

Peive A.V., Yanshin A.L. (Eds), 1980. Tectonics of Northern Eurasia. Explanatory Note to the Tectonic Map of Northern Eurasia. Scale 1:5000000. Nauka, Moscow, 224 p. (in Russian) [Тектоника Северной Евразии: Объяснительная записка к Тектонической карте Северной Евразии масштаба 1:5000000 / Ред. А.В. Пейве, А.Л. Яншин. М.: Наука, 1980. 224 с.].

Peive A.V., Yanshin A.L., Zonenshain L.P., Knipper A.L., Markov M.S., Mossakovsky A.A., Perfiliev A.S., Pushcharovsky Yu.M. et al., 1976. Formation of Continental Crust in Northern Eurasia (in Connection with Construction of a New Tectonic Map). Geotectonics 5, 6-23 (in Russian) [Пейве А.В., Яншин А.Л., Зоненшайн Л.П., Книппер А.Л., Марков М.С., Моссаковский А.А., Перфильев А.С., Пущаровский Ю.М. и др. Становление континентальной земной коры Северной Евразии (в связи с составлением новой тектонической карты) // Геотектоника. 1976. № 5. C. 6-23].

Petrov O.V., Leonov Yu.G., Pospelov I.I. (Eds), 2014a. Tectonics of Nothern, Central and Eastern Asia. Explanatory Note to the Tectonic Map of Northern-Central-Eastern Asia and Adjacent Areas at Scale 1:2500000. VSEGEI Publishing House, Saint Petersburg, $192 \mathrm{p}$.

Petrov O.V., Leonov Yu.G., Tingdong L., Tomurtogoo 0. (Eds), 2014b. Tectonic Map of Northern-Central-Eastern Asia and Adjacent Areas. Scale 1:2500000. In: Atlas of Geological Maps of Northern-Central-Eastern Asia and Adjacent Areas. VSEGEI Publishing House, Saint Petersburg.

Petrov 0., Leonov Yu., Tingdong L., Tomurtogoo O., Ha H.J. (Eds), 2008. Tectonic Map of Central Asia and Adjacent Areas. Scale 1:2500000. VSEGEI Publishing House, Saint Petersburg, 9 sh.

Petrov O., Morozov A., Shokalsky S., Kashubin S., Artemeva I.M., Sobolev N., Petrov E., Ernst R.E., Sergeev S., Smelror M., 2016a. Crustal Structure and Tectonic Model of the Arctic Region. Earth-Science Reviews 154, 29-71. https://doi. org/10.1016/j.earscirev.2015.11.013.

Petrov O.V., Pubelye M. (Eds), 2019. Tectonic map of the Arctic. VSEGEI Publishing House, Saint Petersburg, 72 p. (in Russian) [Тектоническая карта Арктики / Ред. О.В. Петров, М. Пубелье. СПб.: ВСЕГЕИ, 2019. 72 с.].

Petrov O.V., Shuwen D., Kiselev E.A., Morozov A.F. (Eds), 2016b. Atlas of Geological Maps of Asia and Adjacent Areas. International Project. VSEGEI Publishing House, Saint Petersburg, $48 \mathrm{p}$.

Petrov O.V., Smelror M., Morozov A.F. (Eds), 2016c. Atlas of Geological Maps of the Circumpolar Arctic. International Project. VSEGEI Publishing House, Saint Petersburg, 63 p. https://doi.org/10.13140/RG.2.2.30092.51844.

Poselov V., Butsenko V., Chernykh A., Glebovsky V., Jackson H.R., Potter D.P., Oakey G., Shimeld J., Marcussen C., 2014. The Structural Integrity of the Lomonosov Ridge with the North American and Siberian Continental Margins. In: D.B. Stone, G.E. Grikurov, J.G. Clough, G.N. Oakey, D.K. Thurston (Eds), ICAM VI: Proceedings of the International Conference on Arctic Margins VI (Fairbanks, Alaska, May 2011). VSEGEI Publishing House, Saint Petersburg, p. 233-258.

Proskurnin V.F., Petrov O.V., Sobolev N.N., Remizov D.N., Vinogradova N.P., Yudin S.V., 2012. First Data on the Oligocene - Early Cretaceous Continental Magmatism of the Belkovsky Island (New Siberian Islands). Regional Geology and Metallogeny 52, 49-58 (in Russian) [Проскурнин В.Ф., Петров О.В., Соболев Н.Н., Ремизов Д.Н., Виноградова Н.П., Юдин С.В. Первые данные о проявлении олигоцен-раннемиоценового внутриплитного магматизма на о. Бельковский (Новосибирские острова) // Региональная геология и металлогения. 2012. № 52. С. 49-58].

Pushcharovsky Yu.M., 1972. Principles of Tectonic Zoning of Oceans. Geotectonics 6, 18-28 (in Russian) [Пущаровский Ю.М. Принципы тектонического районирования океанов // Геотектоника. 1972. № 6. С. 18-28].

Vernikovsky V.A., Metelkin D.V., Tolmacheva T.Yu., Malyshev N.A., Petrov O.V., Sobolev N.N., Matushkin N.Yu., 2013. Concerning the Issue of Paleotectonic Reconstructions in the Arctic and of the Tectonic Unity of the New Siberian Islands Terrane: New Paleomagnetic and Paleontological Data. Doklady Earth Sciences 451, 791-797. https://doi.org/10. 1134/S1028334X13080072.

Yanshin A.L. (Ed.), 1966. Tectonics of Eurasia. Explanatory Note to the Tectonic Map of Eurasia. Scale 1:5000000. Nauka, Moscow, 488 p. (in Russian) [Тектоника Евразии: Объяснительная записка к Тектонической карте Евразии масштаба 1:5000000 / Ред. А.Л. Яншин. М.: Наука, 1966. 488 с.]. 